Article

\title{
Antitumoural Sulphur and Selenium Heteroaryl Compounds: Thermal Characterization and Stability Evaluation
}

\author{
Verónica Alcolea ${ }^{1,+}$, Pablo Garnica ${ }^{1,+}$, Juan A. Palop ${ }^{1}$, Carmen Sanmartín ${ }^{1, *}$, \\ Elena González-Peñas ${ }^{1}$, Adrián Durán ${ }^{2}$ and Elena Lizarraga ${ }^{1}$ \\ 1 Department of Organic and Pharmaceutical Chemistry, Faculty of Pharmacy and Nutrition, \\ University of Navarra, Irunlarrea 1, 31008 Pamplona, Spain; valcolea@alumni.unav.es (V.A.); \\ pgarnica@alumni.unav.es (P.G.); jpalop@unav.es (J.A.P.); mgpenas@unav.es (E.G.-P.); \\ elizarraga@unav.es (E.L.) \\ 2 Department of Chemistry, Faculty of Sciences, University of Navarra, Irunlarrea 1, 31008 Pamplona, Spain; \\ adrianduran@unav.es \\ * Correspondence: sanmartin@unav.es; Tel.: +34-948-425600 \\ + Authors have contributed equally to this article.
}

Received: 29 June 2017; Accepted: 4 August 2017; Published: 8 August 2017

\begin{abstract}
The physicochemical properties of a compound play a crucial role in the cancer development process. In this context, polymorphism can become an important obstacle for the pharmaceutical industry because it frequently leads to the loss of therapeutic effectiveness of some drugs. Stability under manufacturing conditions is also critical to ensure no undesired degradations or transformations occur. In this study, the thermal behaviour of 40 derivatives of a series of sulphur and selenium heteroaryl compounds with potential antitumoural activity were studied. In addition, the most promising cytotoxic derivatives were analysed by a combination of differential scanning calorimetry, $\mathrm{X}$-ray diffraction and thermogravimetric techniques in order to investigate their polymorphism and thermal stability. Moreover, stability under acid, alkaline and oxidative media was tested. Degradation under stress conditions as well as the presence of polymorphism was found for the compounds VA6E and VA7J, which might present a hurdle to carrying on with formulation. On the contrary, these obstacles were not found for derivative VA4J.
\end{abstract}

Keywords: thermal analysis; activity; stability; polymorphism; differential scanning calorimetry; thermogravimetry; X-ray diffraction; HPLC

\section{Introduction}

Cancer is a leading cause of death worldwide; the World Health Organization estimates the growth rate of new cases to peak at $70 \%$ in the next twenty years [1]. If we draw the focus to US territory, an estimated 1650 deaths per day will be due to cancer [2]. Many treatment patterns include some kind of chemotherapy or molecularly-targeted therapy drugs. Cancer research is nowadays encountering two major obstacles, side-effects and tumour resistance, both intrinsic and acquired [3,4]. Therefore, the synthesis of new, safer and more effective drugs is urgent in order to be able to overcome those previously mentioned difficulties developed by some of the present treatments.

Among the arsenal of new anti-cancer agents, selenium (Se)-containing compounds stand out for their anti-tumour potency and safety [5]. These properties strongly depend on the chemical form and dose used [6]. For the past decade, our group has focused on the synthesis of sulphur (S) and Se-containing molecules as antitumour agents with encouraging results $[7,8]$. In the present study, the homology between those two atoms will be explored in order to widen the variety of chemical entities. 
The introduction of this structural duality will enable us to contrast Se and S influence in terms of anti-cancer activity, stability and thermal characterization.

It has been found that pharmaceutical compounds such as cephalexin, chloramphenicol, digoxin, spironolactone, sulfathiazole, carbamazepine and retroviral agents [9-12] undergo transitions during drying processes, spraying, grinding, compression, excipient addition and the preparation of tableting. Polymorphism in pharmaceutical solids can be a critical manufacturing variable and therefore has to be investigated [13].

Physicochemical properties such as bioavailability and stability are directly related to the crystal structure and possible polymorphism [14,15]. Therefore, the prediction of polymorphism in the early stages of drug development provides valuable information to selectively synthesize or isolate the crystalline structure with the best characteristics. In addition, polymorphic transformations can occur during some steps of the synthesis including purification, crystallization, drying and storage $[16,17]$. Furthermore, this property influences several parameters such as solubility, shelf life, and formulation processes [18].

Investigating the relative thermal stability of polymorphs is also essential because the instant appearance or disappearance of a crystalline structure can lead to serious consequences if the polymorphic transformation occurs in the dosage form [19]. Da Silva et al. [20] have found that the solubility and dissolution properties of finasteride, which is widely used for prostate cancer treatment, were significantly affected by polymorphism. This disparity in bioavailability is related to the diverse dissolution rate of the different polymorphic forms. In some cases, the metastable form of some active ingredients may be twice as active as the stable form [21]. In addition, Yoshida et al. [22] have observed that the degradation products after drug stress conditions are related to some events that appeared in the calorimetric curves.

The study of the physical stability of drugs should be properly conducted in order to determine the characteristics of the proposed formulation and predict possible changes in the solid state of the drug. Certain pharmaceutical processes (granulation, drying, and compression) can lead to polymorphic transformations and thus the critical steps in this process must be identified and controlled to ensure stability until the end of the drug's shelf life [23].

If we narrow the view to Se and $S$ derivatives, those properties have proved to be critical. Some Se-containing structures i.e., ebselen, produce two different polymorphs when crystallized from different solvents that differ in the antioxidant activity related to the ability of Se-N bond cleavage as well as the potential for Se-O interactions [24]. Moreover, $\mathrm{S}$ derivative compounds such as dalcetrapib [25], probenecid [26] or tauroursodeoxycholic acid [27] showed the ability to crystalize in different structures, an ability that dramatically affects their biological activity profile.

Those heteroaryl derivatives that exhibited promising cytotoxic activity (VA7J, VA6O and VA5P) in previous publications from the group $[28,29]$ have the potential to continue the drug discovery process. With the objective of predicting the non-desired transitions or degradation processes that may occur along with the already mentioned pharmaceutical manufacturing processing, we proceeded to the thermal characterization and preliminary stability studies of the leader compounds. In addition, the biological and thermal characterization of the novel compounds recently developed by our group have also been included in this work. Inactive analogues were also studied following the same methodology in order to be able to establish a comparison.

\section{Results and Discussion}

\subsection{Synthesis and Selection Criteria}

The selected compounds for this study were synthesized in the Organic and Pharmaceutical Synthesis Unit of the University of Navarra. A total of 40 compounds were included in this work. They were divided into 12 series (series B to P, Figure 1) according to their central skeleton. They are hybrid derivatives containing diverse substituents with $S$ or Se and several active heterocyclic scaffolds. 
Six novel derivatives (VA6G, VA6H, VA6I, VA2J, VA4J and VA6J) were incorporated to complete the series. The compounds VA6G, VA6H, VA6I and VA6J were synthesized according to a previously published procedure by reaction of the corresponding alkyl halides with potassium thiocyanate in acetone under reflux conditions [30]. To obtain compound VA2J, 2,3-dichloroquinoxaline was treated with thiourea in a 1:2.2 (reagent/thiourea) molar ratio at reflux, using absolute ethanol as solvent. VA4J was synthesized by the treatment of derivative VA2J with a potassium hydroxide solution in DMSO and stirring at room temperature (r.t.), with a posterior methylation with methyl iodide. The final compound was purified taking advantage of its solubility properties. The synthesis of the remaining 34 derivatives has been previously published by our group [28,29].

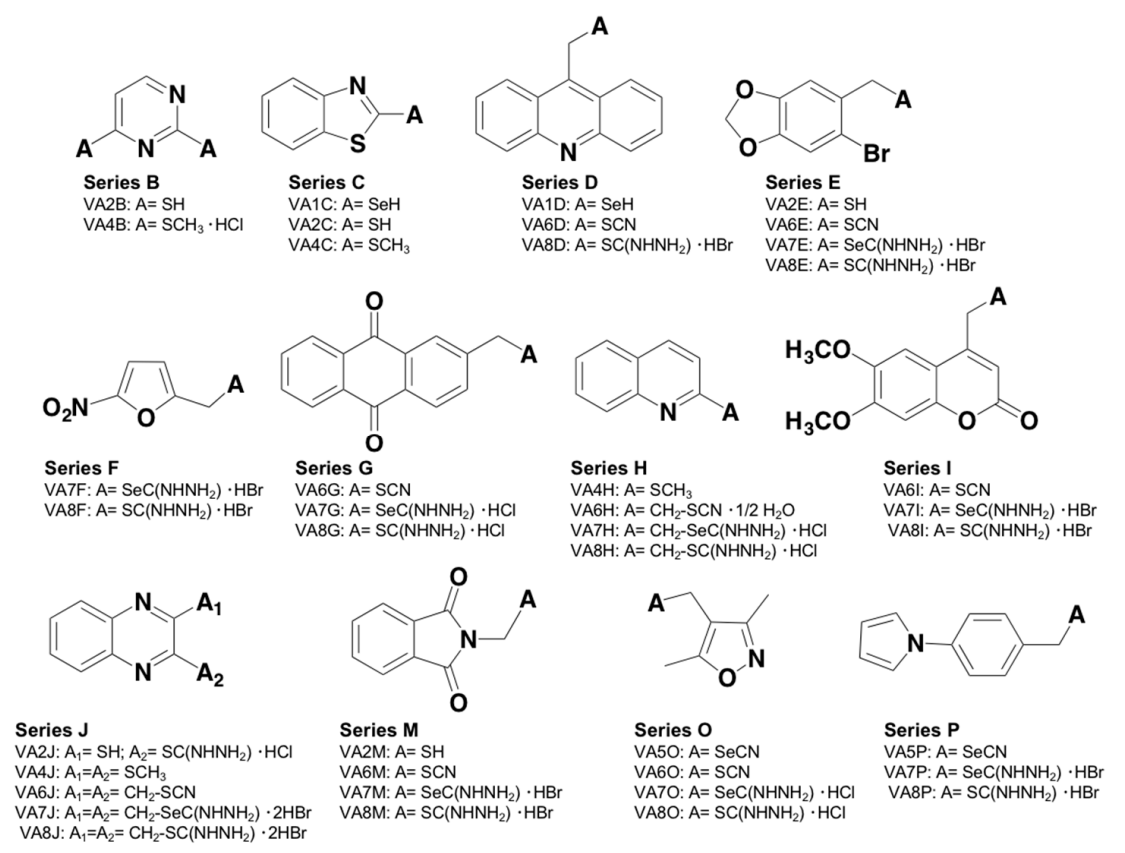

Figure 1. Structures of $S$ and Se heteroaryl compounds studied in this work. The compounds VA6G, VA6H, VA6I, VA2J, VA4J and VA6J are novel molecules. The structures of series 7 and 8 have been previously described [29] and the remaining ones have been extracted from a previous work from our group [28].

In order to perform the thermal characterization and preliminary stability studies of those compounds with the best drug-likeness profile, the cytotoxic potency was evaluated by the MTT (3-(4,5-dimethylthiazol-2-yl)-2,5-diphenyltetrazolium bromide) assay.

The novel synthetic compounds VA2J, VA4J, VA6G, VA6H, VA6I and VA6J were tested in breast adenocarcinoma (MCF-7) and non-malignant mammary-gland-derived (184B5) cell lines to be able to establish their potency and selectivity. The reference drug used was methylseleninic acid (MSA) as a Se-containing structure with promising in vitro and in vivo results against different tumour types $[31,32]$. Results are expressed as the concentration that inhibits $50 \%$ cell growth $\left(\mathrm{GI}_{50}\right)$, the concentration that inhibits completely cell growth (TGI) and the concentration that kills $50 \%$ of cells $\left(\mathrm{LD}_{50}\right)$. The selectivity index (SI) is calculated as $\mathrm{GI}_{50}(184 \mathrm{~B} 5) / \mathrm{GI}_{50}(\mathrm{MCF}-7)$.

As shown in Table 1, five out of the six tested compounds (VA2J, VA4J, VA6G, VA6H and VA6I) exhibited $\mathrm{GI}_{50}$ values under $10 \mu \mathrm{M}$. If we move to selectivity values, the compound VA4J emerges as the most selective derivative with an SI over 50 times higher than MSA.

For the remaining compounds of series 1, 2, 3, 4, 5 and 6, cytotoxic activity had already been evaluated following the same methodology [28]. Cell viability assays for compounds of series 7 and 8 had already been screened in a panel of six human cancer cell lines: 1205Lu (melanoma), A549 (lung), DU145 (prostate), HCT116 (colon), PANC-1 (pancreas) and BxPC3 (pancreas) [29]. 
Table 1. Average values of $\mathrm{GI}_{50}$, TGI and $\mathrm{LD}_{50}(\mu \mathrm{M})$ and calculated SI.

\begin{tabular}{|c|c|c|c|c|c|c|c|}
\hline \multirow{3}{*}{ Compound } & \multicolumn{6}{|c|}{ Cell Lines } & \multirow{3}{*}{ SI } \\
\hline & \multicolumn{3}{|c|}{ MCF-7 } & \multicolumn{3}{|c|}{ 184B5 } & \\
\hline & $\mathrm{GI}_{50}$ & TGI & $\mathrm{LD}_{50}$ & $\mathrm{GI}_{50}$ & TGI & $\mathrm{LD}_{50}$ & \\
\hline VA2J & 2.20 & 13.90 & 44.02 & 12.45 & 15.97 & 20.48 & 5.66 \\
\hline VA4J & 1.02 & $>100$ & $>100$ & 52.45 & $>100$ & $>100$ & 51.25 \\
\hline VA6G & 3.59 & 23.95 & 67.27 & 14.29 & 34.32 & 64.84 & 3.99 \\
\hline VA6H & 8.53 & 14.83 & 24.18 & 27.76 & 75.84 & $>100$ & 3.25 \\
\hline VA6I & 4.51 & $>100$ & $>100$ & 2.26 & $>100$ & $>100$ & 0.50 \\
\hline VA6J & 18.50 & 50.55 & 83.93 & 39.77 & 69.80 & 94.62 & 2.15 \\
\hline MSA & 1.28 & 3.43 & $>100$ & 1.79 & 3.84 & $>100$ & 1.40 \\
\hline
\end{tabular}

Based on all the synthetic data and antitumour preliminary activity evaluation, the following criteria were established to select the most promising structures to proceed to their thermal characterization and preliminary stability studies:

- Synthetic yield has to be higher than $40 \%$ as lower yields might present limitations to a future production scale-up.

- High activity against cancer cells must be exhibited.

Taking into account these criteria, the structure VA4J was chosen as the most promising one of the newly studied structures with a yield of $53 \%$, GI ${ }_{50}$ value against MCF-7 cells under $10 \mu \mathrm{M}$ and an SI of 51.25 .

Derivative VA7J was selected from series 7 and 8 with $82 \%$ yield and the most potent activity profile. Even though the MTT assay conditions were slightly different in this work, a clear leader can be established. Compound VA7J was selected from this group of structures as it shows $\mathrm{IC}_{50}$ values under $10 \mu \mathrm{M}$ in all six cell lines even at short time points.

Focusing on the compounds remaining of series 1, 2, 3, 4, 5 and 6, compounds VA6O and VA5P were selected in the referenced work as the most potent ones. Nevertheless, VA6O and VA5P had to be dismissed for this study as VA6O has an oily physical appearance and VA5P showed fusion with decomposition in a preliminary test. Therefore, we followed the criteria of SI, potency and potential safety, to select the representative compound for these structures. According to these criteria, derivatives VA2E and VA6E were chosen. Compound VA2E did not meet the yield condition with a $5 \%$ yield, so it was ruled out. Finally, the compound VA6E was selected as it has a reasonable yield, high potency and it is fourteen times more selective than MSA [28].

\subsection{Compound Thermal Characterization}

The combination of several techniques is necessary in order to properly confirm polymorphism presence and thermal stability. The methodology employed to perform the complete thermal characterization of a compound include IR spectroscopy, powder X-ray diffractometry (PXRD) and thermal methods, especially differential scanning calorimetry (DSC) and thermogravimetry (TG).

\subsubsection{Compound VA6E}

The DSC results of compound VA6E are shown in Figure 2a and Table 2. During the first thermal scan (curve A), three processes were observed. The first corresponds with a typical endothermic process of the original product (Form I), followed by a recrystallization process to another form (Form II), which then melts. After cooling, in the sample-through a polymorphic phase transition-Form II changes into another form which shows fusion processes (Form III, curve B). In the third scan a new endothermic process happened at a lower temperature (curve $C$ ), with the appearance of a new polymorph (Form IV). The complete thermogram (Figure 2b) shows that other processes at another temperature (higher or lower) can be excluded. 


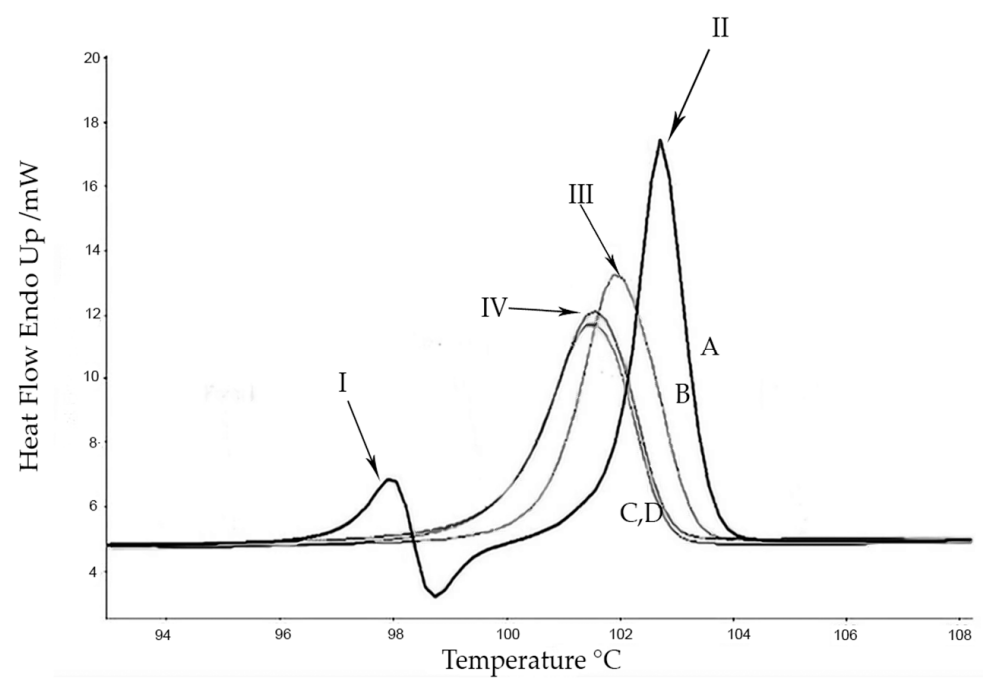

(a)

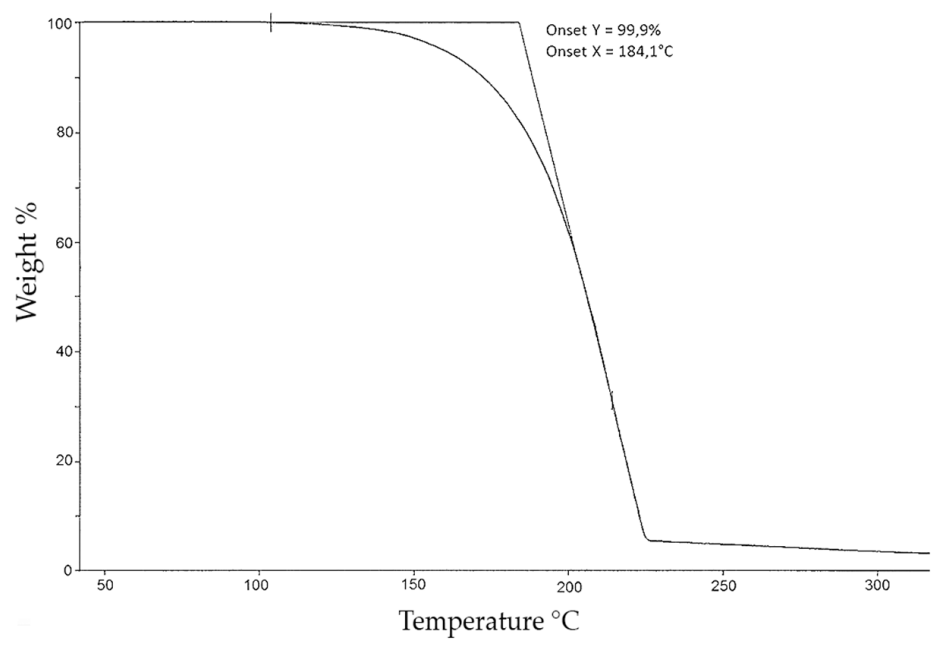

(b)

Figure 2. DSC and TG of compound VA6E (a,b) respectively. (a) Curve A: first scan (fusion Form I and Form II); curve B: second scan (fusion of Form III) and curves C and D: third and fourth scan (fusion of Form IV); (b) TG of compound VA6E at $10^{\circ} \mathrm{C} / \mathrm{min}$.

Table 2. Fusion-recrystallization of compound VA6E.

\begin{tabular}{|c|c|c|c|c|c|c|}
\hline \multirow{2}{*}{ Scan } & \multicolumn{2}{|c|}{ Form I } & \multicolumn{2}{|c|}{ Recrystallization } & \multicolumn{2}{|c|}{ New Polymorphs } \\
\hline & $T_{\text {onset }}\left({ }^{\circ} \mathrm{C}\right)$ & $\Delta H\left(\mathrm{~J} \mathrm{~g}^{-1}\right)$ & $T_{\text {onset }}\left({ }^{\circ} \mathrm{C}\right)$ & $\Delta H\left(\mathrm{~J} \mathrm{~g}^{-1}\right)$ & $T_{\text {onset }}\left({ }^{\circ} \mathrm{C}\right)$ & $\Delta H\left(\mathrm{~J} \mathrm{~g}^{-1}\right)$ \\
\hline 1 st & 97.2 & 7.9 & 98.5 & -8.8 & 101.9 & 75.6 \\
\hline & \multicolumn{2}{|c|}{ 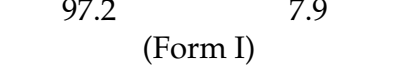 } & & & \multicolumn{2}{|c|}{ (Form II) } \\
\hline \multirow[t]{2}{*}{ 2nd } & - & - & - & - & 100.7 & 80.3 \\
\hline & & & & & \multicolumn{2}{|c|}{ (Form III) } \\
\hline \multirow[t]{2}{*}{$3 r d$} & - & - & - & - & 100.1 & 76.7 \\
\hline & & & & & \multicolumn{2}{|c|}{ (Form IV) } \\
\hline \multirow[t]{2}{*}{4 th } & - & - & - & - & 99.9 & 76.0 \\
\hline & & & & & \multicolumn{2}{|c|}{ (Form IV) } \\
\hline
\end{tabular}


Marked differences were found in the positions of the peaks between the diffractograms of the different forms. In Figure 3, the diffractogram in black corresponds to the sample after melting and the subsequent recrystallization. Some of the peaks matched with those from the original sample (diffractogram in red). However, other peaks only appeared after melting and recrystallization $\left(2 \theta=6.7^{\circ}, 13.4^{\circ}, 20.3^{\circ}, 22.8^{\circ}, 29.2^{\circ}, 33.9^{\circ}\right.$ and $\left.34.1^{\circ}\right)$. In this case, we think Form I has partially transformed into another polymorphic form (Form II), while preserving part of the original form.

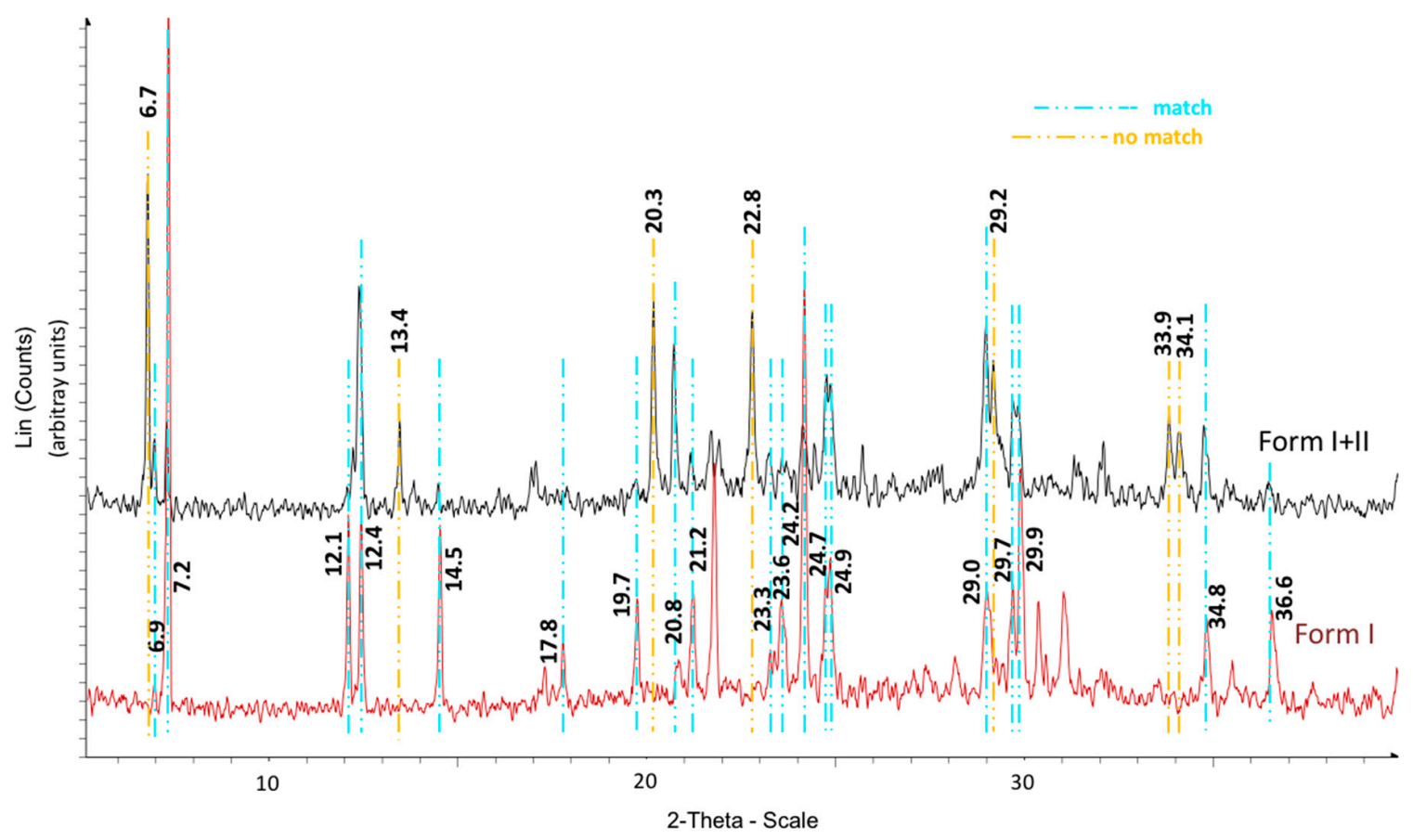

Figure 3. X-ray diffractograms for compound VA6E. Form I shows the diffractogram of the original polymorph and Form I + II, the one obtained after one cycle of melting-recrystallization.

Figure 4 shows the X-ray diffractograms after different and consecutive melting-recrystallization cycles. As discussed before, after one cycle, a mixture of Forms I and II can be observed. The following cycle provoked the appearance of a new polymorphic form (Form III), but the original Forms I and II are also present (diffractogram in red) as the match of the position of the peaks $2 \theta=20.3^{\circ}, 20.8^{\circ}$, $23.3^{\circ}$, and $24.9^{\circ}$ shows. Form III (diffractogram in blue) showed a peak at $2 \theta=20.4^{\circ}$ that was not detected in Forms I and II, as well as the absence of other signals present in Forms I and II (peaks at $2 \theta=7.2^{\circ}$ and $34.8^{\circ}$ ). Finally, Form IV was observed after another cycle (diffractogram in green). The differences between the resulting form from this last cycle and the previous ones are highlighted in yellow dotted lines. Peaks at $2 \theta=20.4^{\circ}, 29.8^{\circ}$ and $30.8^{\circ}$ are present in Form III but not in the last polymorphic form. Peaks at $7.2^{\circ}$ and $34.8^{\circ}$, present in Form I + II, do not appear in Form IV. After successive heating-cooling processes the same Form IV was isolated. Taken together, the results of the X-ray diffraction indicate that all four forms observed by DSC were indeed distinct. 


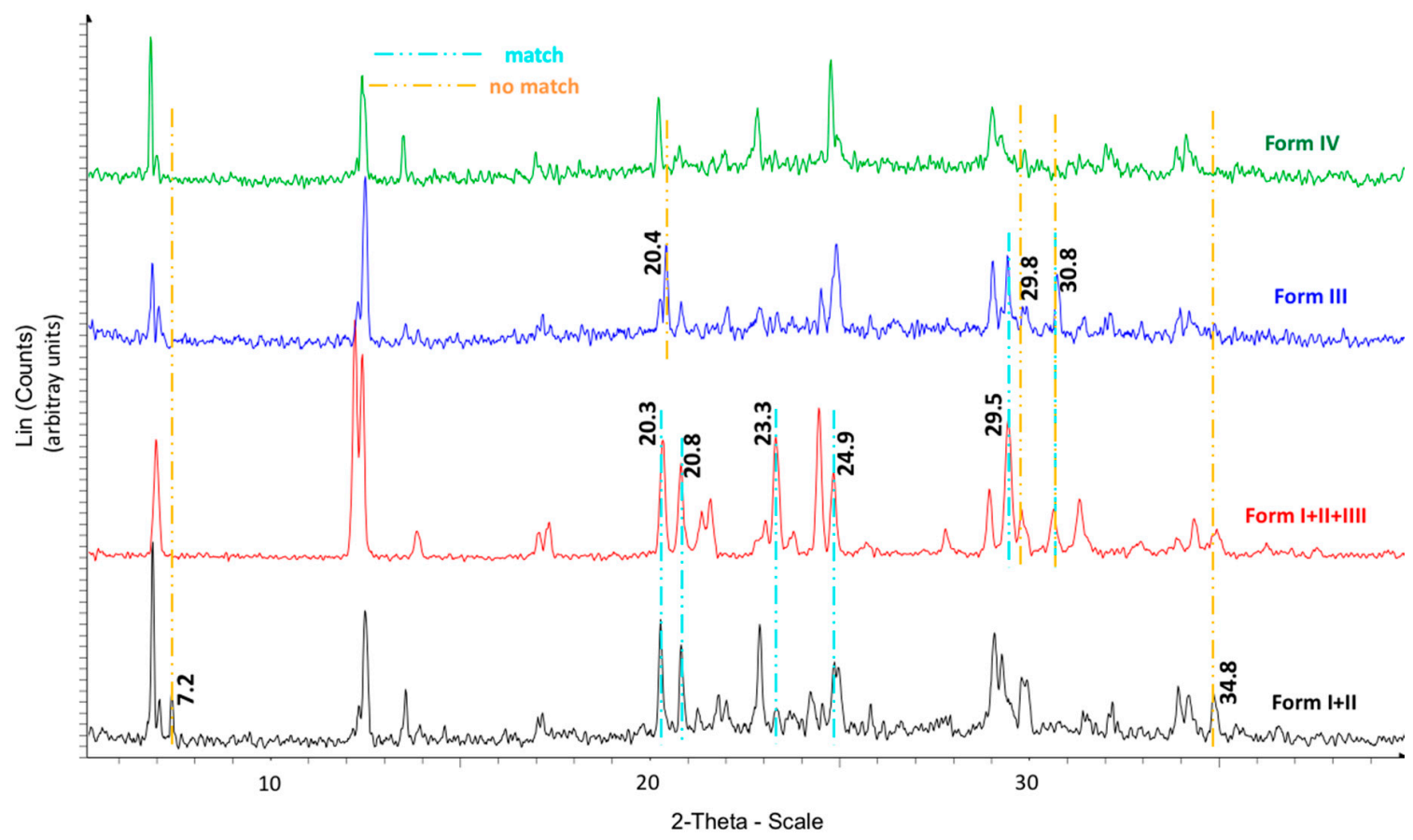

Figure 4. X-ray diffractograms of the forms of VA6E obtained after successive cycles of melting-recrystallization.

\subsubsection{Compound VA4J}

DSC results (Figure 5a and Table 3) show that the compound VA4J does not alter its thermal behaviour after an initial fusion-recrystallization cycle. Under these conditions there is no evidence of polymorphism. During the first thermal curve of compound VA4J (curve A in Figure 5a), a classic endothermic process of Form I was discerned (Table 3), typical of a melting process. After cooling the sample, the melted form recrystallized in the same form, as indicated by the same endothermic process in curve $B$.

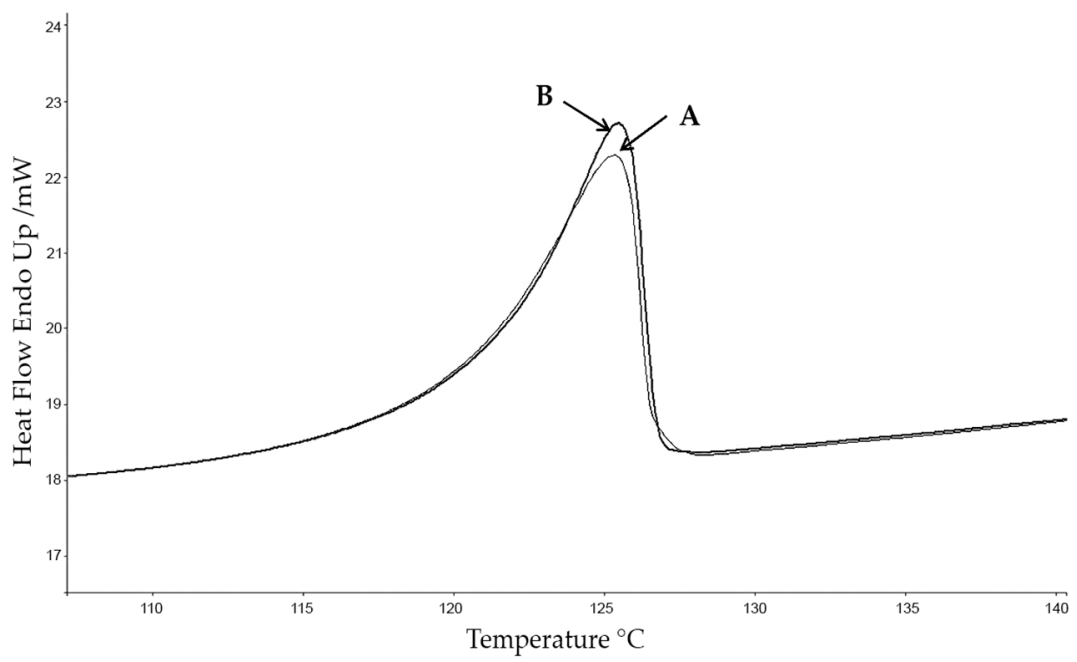

(a)

Figure 5. Cont. 


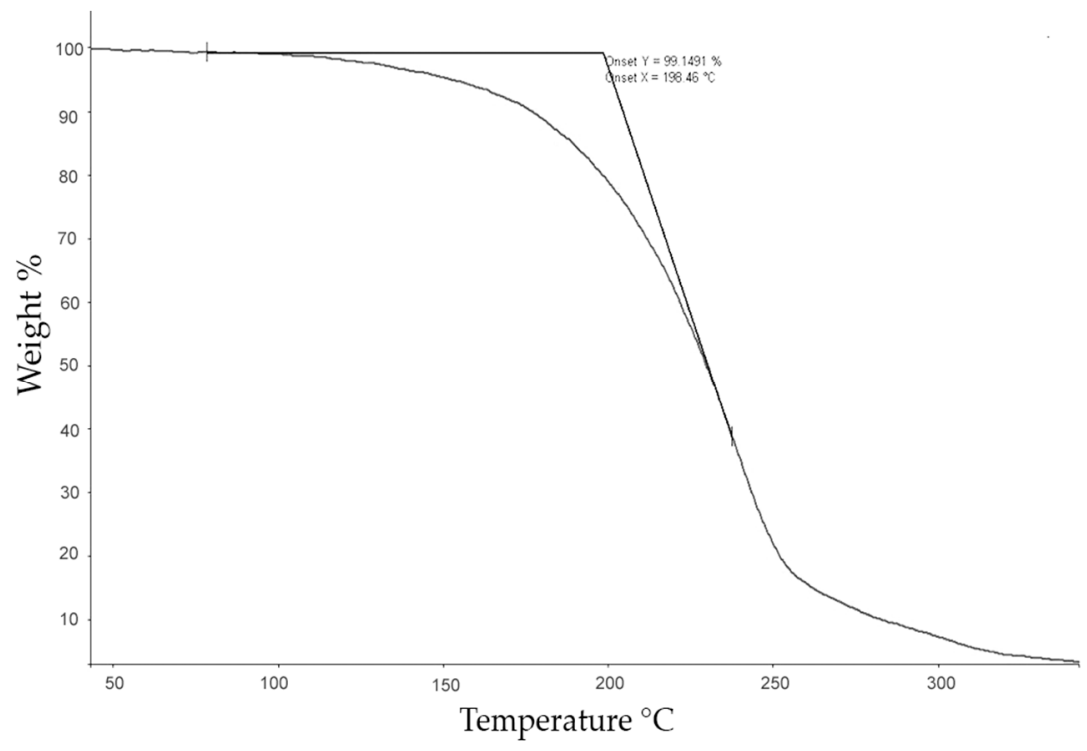

(b)

Figure 5. DSC (a) and TG (b) of compound VA4J. (a) Curve A: first scan (fusion of Form I) and curve B: second scan (fusion of recrystallized form); (b) TG of compound VA4J at $10{ }^{\circ} \mathrm{C} / \mathrm{min}$.

Table 3. Fusion-recrystallization of compound VA4J.

\begin{tabular}{cccl}
\hline & $\boldsymbol{T}_{\text {onset }}\left({ }^{\circ} \mathrm{C}\right)$ & $\boldsymbol{\Delta H}\left(\mathbf{J ~ g}^{-\mathbf{1}}\right)$ & \\
\hline 1st scan & 119.84 & 93.58 & Form I \\
2nd scan & 119.59 & 93.91 & Form I \\
\hline
\end{tabular}

To further confirm the absence of polymorphism, both samples were analysed by using PXRD. An excellent match of the position of the peaks in both diffractograms was observed (see peaks at $2 \theta$ at $11.5^{\circ}, 11.9^{\circ}, 20.9^{\circ}, 24.1^{\circ}, 26.2^{\circ}, 27.6^{\circ}, 29.3^{\circ}$ and $33.0^{\circ}$ in Figure 6$)$. The differences in the relative intensities of some of the peaks were probably due to some preferred orientation in the samples derived from the absence of random orientation of crystal grains in space.

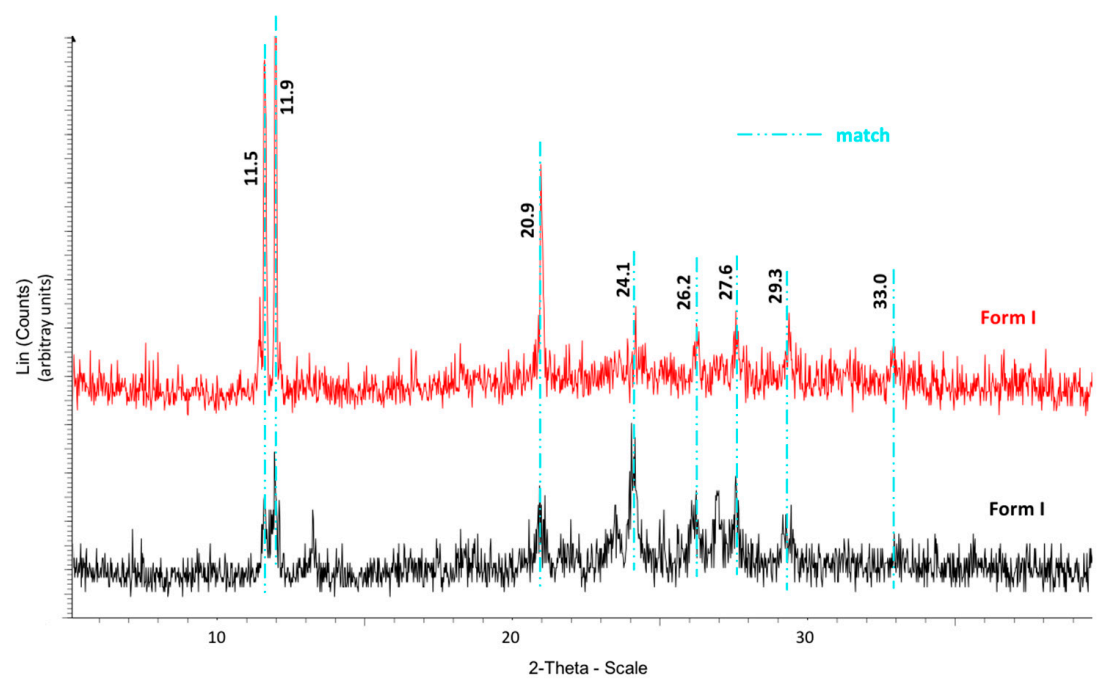

Figure 6. X-ray diffractograms of the original form of VA4J (in black) and those obtained after successive cycles of melting-recrystallization (in red). 


\subsubsection{Compound VA7J}

In the first heating scan, the original form of compound VA7J melts with desolvation. A new endothermic fusion of the anhydrous product generated confirms the polymorphism (pseudopolymorphism or phase transition of the hydrated form to the corresponding anhydride) of this compound (curve A, Figure 7a). After cooling the sample, it can be observed (curve B) that the subsequent endothermic process occurs at the same temperature (curve B, Figure 7a, Table 4).

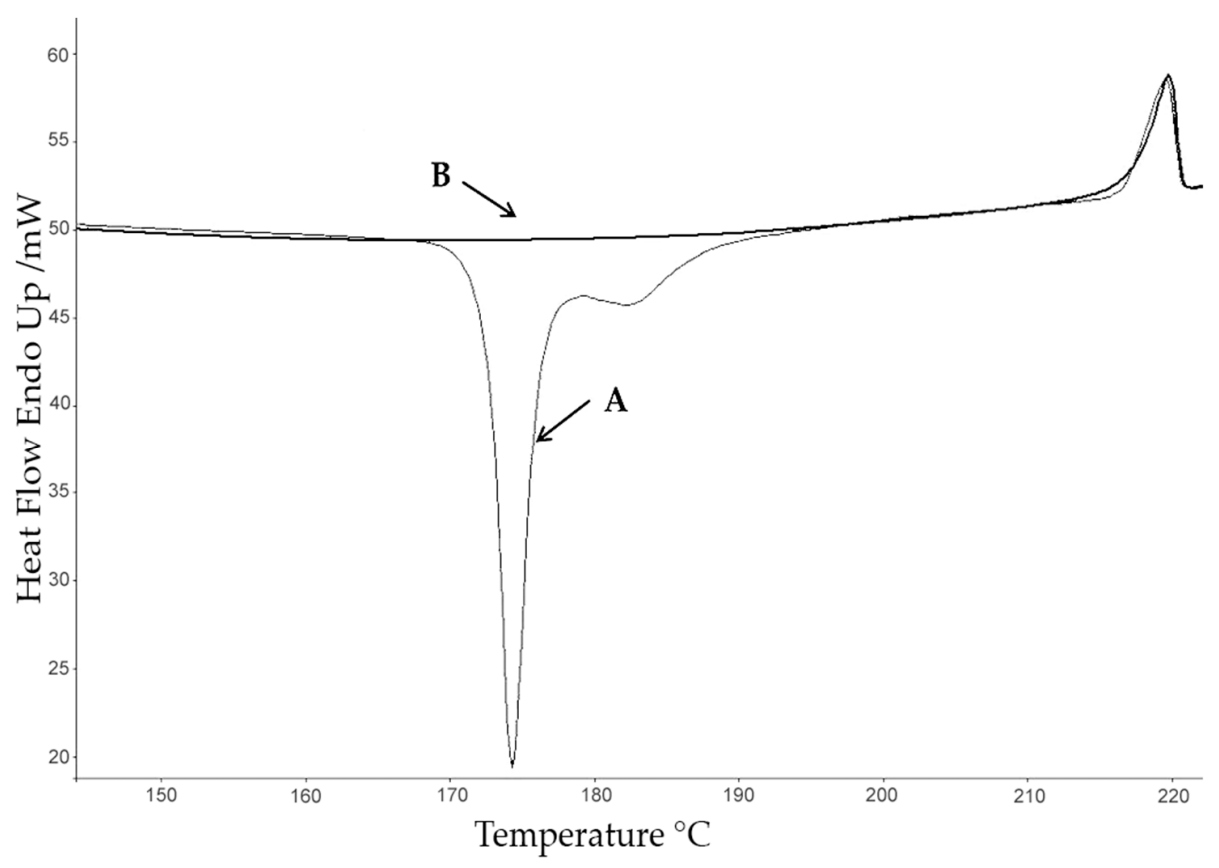

(a)

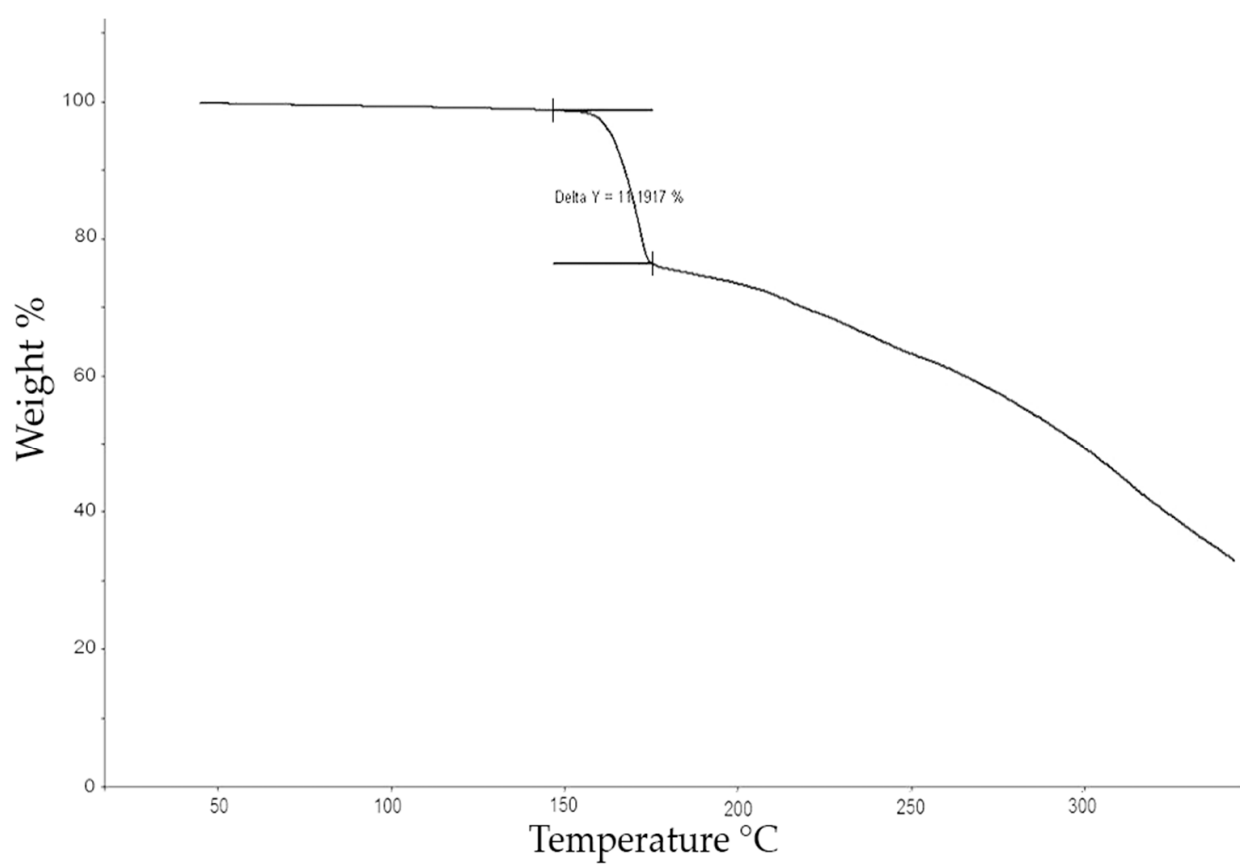

(b)

Figure 7. DSC (a) and TG (b) of compound VA7J. (a) Curve A: first scan (desolvation) and curve B: second scan; (b) TG of compound VA7J at $10^{\circ} \mathrm{C} / \mathrm{min}$. 
Table 4. Fusion-recrystallization of compound VA7J.

\begin{tabular}{cccl}
\hline Behaviour III & $\boldsymbol{T}_{\text {onset }}\left({ }^{\circ} \mathrm{C}\right)$ & $\Delta \boldsymbol{H}\left(\mathbf{J ~ g ~}^{-\mathbf{1}}\right)$ & \\
\hline \multirow{2}{*}{ 1st scan } & 173.8 & -88.4 & Form I \\
& 218.2 & 18.7 & Form II \\
\hline 2nd scan & 219.7 & 17.4 & Form II \\
\hline
\end{tabular}

Two different compounds were detected in the sample VA7J by using PXRD (Figure 8). Several differences were found between the peak positions in the raw sample (diffractogram in black) and the sample after one desolvation/phase transition process (diffractogram in red). Peaks at $2 \theta=19.3^{\circ}, 21.2^{\circ}, 22.1^{\circ}, 23.8^{\circ}, 24.7^{\circ}, 26.6^{\circ}, 28.4^{\circ}$ and $32.7^{\circ}$ were present in the original compound (Form I) but disappeared in Form II of anhydre compound. This confirms the appearance of a new polymorphic form.

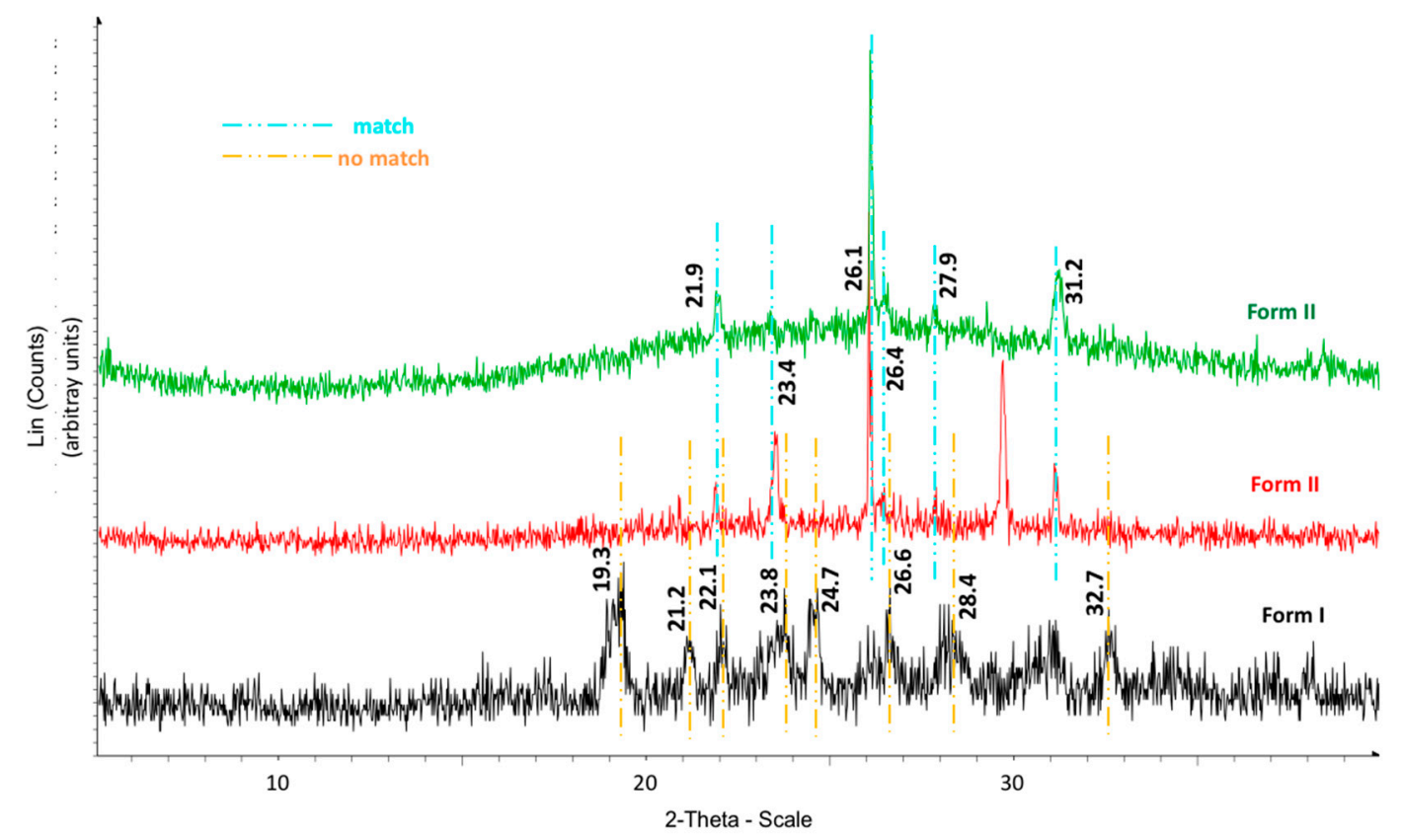

Figure 8. X-ray diffractograms of the forms of VA7J obtained after successive cycles of melting-recrystallization.

The diffractogram collected after a melting scan and a subsequent recrystallization process of Form II of the compound (diffractogram in green) is very similar to the one obtained from the first cycle (in red). Therefore, a new polymorphic form is not present. In Figure 8, the majority of the diffraction peaks match in the $2 \theta$ position (see peaks at $2 \theta=21.9^{\circ}, 23.4^{\circ}, 26.1^{\circ}, 26.4^{\circ}, 27.9^{\circ}$ and $31.2^{\circ}$ ) and the observed differences between both diffractograms are in terms of the relative intensities.

\subsection{Compound Stablity Tests}

\subsubsection{Thermal Stability}

Thermogravimetric analyses were performed to evaluate the thermal stability of the compounds (Figures $2 \mathrm{~b}, 5 \mathrm{~b}$ and $7 \mathrm{~b}$, Table 5 . The TG analysis of the compounds VA4J and VA6E show that the decomposition or desolvation processes in the temperature range studied $\left(100-135^{\circ} \mathrm{C}\right.$ and $94-108{ }^{\circ} \mathrm{C}$, respectively) can be excluded. On the other hand, the thermogravimetric curve of the compound VA7J shows a debromhidration process at $173^{\circ} \mathrm{C}$, and when further heated, decomposition of desolvated compound from $228^{\circ} \mathrm{C}$. 
Table 5. Thermal data obtained by DSC and TG.

\begin{tabular}{|c|c|c|c|c|c|c|}
\hline \multirow{2}{*}{ Ref. } & \multirow{2}{*}{$\mathbf{R}$} & \multicolumn{4}{|c|}{ DSC } & \multirow{2}{*}{$\begin{array}{c}\mathrm{TG} \\
\mathrm{T}_{\mathrm{o}} /{ }^{\circ} \mathrm{C}\end{array}$} \\
\hline & & Scan & $\mathrm{T}_{0} /{ }^{\circ} \mathrm{C}$ & $\Delta H_{f} / \mathrm{J} \mathrm{g}^{-1}$ & Behaviour & \\
\hline \multicolumn{7}{|c|}{ Series B } \\
\hline VA2B & $\mathrm{SH}$ & 1st & - & - & $\mathrm{V}$ & 263.3 \\
\hline VA4B & $\mathrm{SCH}_{3}$ & $1 \mathrm{st}$ & - & - & $\mathrm{V}$ & 103.5 \\
\hline \multicolumn{7}{|c|}{ Series C } \\
\hline VA1C & $\mathrm{SeH}$ & $\begin{array}{l}\text { 1st } \\
2 \mathrm{nd}\end{array}$ & $\begin{array}{c}175.5 \\
-\end{array}$ & $\begin{array}{c}91.3 \\
-\end{array}$ & I & 218.4 \\
\hline VA2C & $\mathrm{SH}$ & $\begin{array}{l}\text { 1st } \\
2 \mathrm{nd}\end{array}$ & $\begin{array}{l}178.8 \\
178.6\end{array}$ & $\begin{array}{l}85.9 \\
86.6\end{array}$ & III & 224.7 \\
\hline VA4C & $\mathrm{SCH}_{3}$ & $1 \mathrm{st}$ & - & - & $\mathrm{V}$ & 131.8 \\
\hline \multicolumn{7}{|c|}{ Series D } \\
\hline VA1D & $\mathrm{SeH}$ & 1 st & - & - & $\mathrm{V}$ & 244.7 \\
\hline VA6D & $\mathrm{SCN}$ & 1st & - & - & $\mathrm{V}$ & 205.0 \\
\hline VA8D & $\mathrm{SC}\left(\mathrm{NHNH}_{2}\right)$ & 1 st & 196.7 & -90.3 & $*$ & 193.1 \\
\hline \multicolumn{7}{|c|}{ Series E } \\
\hline VA2E & $\mathrm{SH}$ & $\begin{array}{c}1 \mathrm{st} \\
2 \mathrm{nd}\end{array}$ & $\begin{array}{c}148.8 \\
-\end{array}$ & $\begin{array}{c}34.0 \\
-\end{array}$ & I & 266.2 \\
\hline VA6E & $\mathrm{SCN}$ & $\begin{array}{l}\text { 1st } \\
\text { 2nd } \\
\text { 3th } \\
4 \text { th }\end{array}$ & $\begin{array}{c}97.2 \\
98.4 \\
101.9 \\
100.7 \\
100.1 \\
99.9\end{array}$ & $\begin{array}{c}7.8 \\
-8.8 \\
75.6 \\
80.3 \\
76.7 \\
76.0\end{array}$ & IV & 184.1 \\
\hline VA7E & $\mathrm{SeC}\left(\mathrm{NHNH}_{2}\right)$ & $\begin{array}{l}1 \mathrm{st} \\
2 \mathrm{nd} \\
3 \mathrm{th}\end{array}$ & $\begin{array}{c}183.8 \\
177.2 \\
-\end{array}$ & $\begin{array}{c}21.5 \\
28.1 \\
-\end{array}$ & II & 205.2 \\
\hline VA8E & $\mathrm{SC}\left(\mathrm{NHNH}_{2}\right)$ & $\begin{array}{l}\text { 1st } \\
\text { 2nd }\end{array}$ & $\begin{array}{c}196.1 \\
208.5 \\
-\end{array}$ & $\begin{array}{c}33.8 \\
-37.4 \\
- \\
\end{array}$ & I & 215.1 \\
\hline \multicolumn{7}{|c|}{ Series F } \\
\hline VA7F & $\mathrm{SeC}\left(\mathrm{NHNH}_{2}\right)$ & 1 st & 214.4 & -63.6 & * & 214.7 \\
\hline VA8F & $\mathrm{SC}\left(\mathrm{NHNH}_{2}\right)$ & 1st & 198.3 & -64.6 & $*$ & 190.8 \\
\hline \multicolumn{7}{|c|}{ Series G } \\
\hline VA6G & SCN & 1 st & - & - & $\mathrm{V}$ & 238.3 \\
\hline VA7G & $\mathrm{SeC}\left(\mathrm{NHNH}_{2}\right)$ & 1 st & - & - & $\mathrm{V}$ & 198.2 \\
\hline VA8G & $\mathrm{SC}\left(\mathrm{NHNH}_{2}\right)$ & 1 st & - & - & $\mathrm{V}$ & 243.7 \\
\hline \multicolumn{7}{|c|}{ Series H } \\
\hline VA4H & $\mathrm{SCH}_{3}$ & $\begin{array}{c}1 \mathrm{st} \\
2 \mathrm{nd}\end{array}$ & $\begin{array}{c}54.9 \\
- \\
\end{array}$ & $\begin{array}{c}75.7 \\
- \\
\end{array}$ & I & 105.6 \\
\hline VA6H & $\mathrm{SCN}$ & $\begin{array}{c}1 \mathrm{st} \\
2 \mathrm{nd}\end{array}$ & $\begin{array}{c}78.9 \\
-\end{array}$ & $\begin{array}{c}116.6 \\
-\end{array}$ & I & 139.1 \\
\hline VA7H & $\mathrm{SeC}\left(\mathrm{NHNH}_{2}\right)$ & $\begin{array}{l}\text { 1st } \\
2 \text { nd }\end{array}$ & $\begin{array}{c}113.7 \\
-\end{array}$ & $\begin{array}{c}42.0 \\
-\end{array}$ & I & 145.8 \\
\hline VA8H & $\mathrm{SC}\left(\mathrm{NHNH}_{2}\right)$ & $\begin{array}{l}\text { 1st } \\
2 \mathrm{nd}\end{array}$ & $\begin{array}{c}176.2 \\
-\end{array}$ & $\begin{array}{c}49.3 \\
-\end{array}$ & I & 190.2 \\
\hline
\end{tabular}


Table 5. Cont

\begin{tabular}{|c|c|c|c|c|c|c|}
\hline \multirow{2}{*}{ Ref. } & \multirow{2}{*}{$\mathbf{R}$} & \multicolumn{4}{|c|}{ DSC } & \multirow{2}{*}{$\begin{array}{c}\text { TG } \\
\mathrm{T}_{\mathrm{o}} /{ }^{\circ} \mathrm{C}\end{array}$} \\
\hline & & Scan & $\mathrm{T}_{\mathrm{o}} /{ }^{\circ} \mathrm{C}$ & $\Delta H_{f} / \mathrm{J} \mathrm{g}^{-1}$ & Behaviour & \\
\hline \multicolumn{7}{|c|}{ Series I } \\
\hline VA6I & $\mathrm{SCN}$ & $\begin{array}{l}\text { 1st } \\
2 \text { nd }\end{array}$ & $\begin{array}{c}234.9 \\
-\end{array}$ & $\begin{array}{c}110.8 \\
-\end{array}$ & I & 246.9 \\
\hline VA7I & $\mathrm{SeC}\left(\mathrm{NHNH}_{2}\right)$ & 1 st & $\begin{array}{l}230.1 \\
234.4\end{array}$ & $\begin{array}{c}30.1 \\
-14.4\end{array}$ & * & 226.4 \\
\hline VA8I & $\mathrm{SC}\left(\mathrm{NHNH}_{2}\right)$ & 1st & $\begin{array}{l}263.2 \\
265.4 \\
\end{array}$ & $\begin{array}{c}39.6 \\
-36.7 \\
\end{array}$ & * & 272.4 \\
\hline \multicolumn{7}{|c|}{ Series J } \\
\hline VA2J & $\mathrm{SH} / \mathrm{SC}\left(\mathrm{NHNH}_{2}\right)$ & 1 st & 206.5 & -63.9 & * & 199.2 \\
\hline VA4J & $\mathrm{SCH}_{3}$ & 1 st & $\begin{array}{l}119.84 \\
119.59\end{array}$ & $\begin{array}{l}93.58 \\
93.91\end{array}$ & I & 197.42 \\
\hline VA6J & $\mathrm{SCN}$ & 2nd & 167.6 & -227.0 & * & 165.0 \\
\hline VA7J & $\mathrm{SeC}\left(\mathrm{NHNH}_{2}\right)$ & $\begin{array}{l}\text { 1st } \\
\text { 2nd } \\
3 \text { th }\end{array}$ & $\begin{array}{l}173.8 \\
218.2 \\
219.7 \\
219.6\end{array}$ & $\begin{array}{c}-88.4 \\
18.5 \\
17.4 \\
17.4\end{array}$ & IV & From 228 \\
\hline VA8J & $\mathrm{SC}\left(\mathrm{NHNH}_{2}\right)$ & $\begin{array}{l}\text { 1st } \\
\text { 2nd }\end{array}$ & $\begin{array}{c}222.9 \\
224.1 \\
- \\
\end{array}$ & $\begin{array}{c}31.3 \\
-95.3 \\
- \\
\end{array}$ & I & 251.05 \\
\hline \multicolumn{7}{|c|}{ Series $\mathbf{M}$} \\
\hline VA2M & $\mathrm{SH}$ & $\begin{array}{l}1 \mathrm{st} \\
2 \mathrm{nd}\end{array}$ & $\begin{array}{l}113.6 \\
110.2 \\
\end{array}$ & $\begin{array}{l}68.1 \\
70.7 \\
\end{array}$ & III & 166.0 \\
\hline VA6M & $\mathrm{SCN}$ & $\begin{array}{c}1 \text { st } \\
2 \text { nd }\end{array}$ & $\begin{array}{c}143.3 \\
-\end{array}$ & $\begin{array}{c}50.8 \\
-\end{array}$ & I & 164.8 \\
\hline VA7M & $\mathrm{SeC}\left(\mathrm{NHNH}_{2}\right)$ & $\begin{array}{l}2 \text { nd } \\
3 \text { th }\end{array}$ & $\begin{array}{l}211.6 \\
216.0 \\
220.0 \\
219.7 \\
219.8 \\
\end{array}$ & $\begin{array}{c}34.4 \\
-68.7 \\
4.4 \\
10.3 \\
14.8 \\
\end{array}$ & IV & 255.8 \\
\hline VA8M & $\mathrm{SC}\left(\mathrm{NHNH}_{2}\right)$ & $\begin{array}{c}\text { 1st } \\
2 \text { nd }\end{array}$ & $\begin{array}{c}228.7 \\
-\end{array}$ & $\begin{array}{c}116.7 \\
-\end{array}$ & I & 233.1 \\
\hline \multicolumn{7}{|c|}{ Series $\mathrm{O}$} \\
\hline VA5O & $\mathrm{SeCN}$ & $\begin{array}{l}1 \text { st } \\
2 \text { nd }\end{array}$ & $\begin{array}{l}67.7 \\
65.6 \\
\end{array}$ & $\begin{array}{l}76.0 \\
66.2 \\
\end{array}$ & III & 141.7 \\
\hline VA7O & $\mathrm{SeC}\left(\mathrm{NHNH}_{2}\right)$ & 1 st & - & - & $\mathrm{V}$ & 185.9 \\
\hline VA8O & $\mathrm{SC}\left(\mathrm{NHNH}_{2}\right)$ & $\begin{array}{c}1 \text { st } \\
2 \text { nd } \\
3 \text { rd }\end{array}$ & $\begin{array}{c}194.7 \\
199.8 \\
- \\
\end{array}$ & $\begin{array}{c}21.1 \\
45.8 \\
- \\
\end{array}$ & II & 201.8 \\
\hline \multicolumn{7}{|c|}{ Series $\mathbf{P}$} \\
\hline VA5P & SeCN & 1 st & 161.3 & 79.6 & * & 149.4 \\
\hline VA7P & $\mathrm{SeC}\left(\mathrm{NHNH}_{2}\right)$ & 1st & 180.2 & -84.7 & * & 175.8 \\
\hline VA8P & $\mathrm{SC}\left(\mathrm{NHNH}_{2}\right)$ & $\begin{array}{l}\text { 1st } \\
\text { 2nd }\end{array}$ & $\begin{array}{l}200.6 \\
210.1\end{array}$ & $\begin{array}{c}1.7 \\
-60.4\end{array}$ & * & 199.8 \\
\hline
\end{tabular}

\subsubsection{Stability after Stress Conditions}

The stability of compounds VA4J (without polymorphic behaviour) and VA6E and VA7J (with polymorphic behaviour) was investigated after the application of diverse stress conditions: acid 
hydrolysis $(\mathrm{HCl} 1 \mathrm{M})$, basic hydrolysis $(\mathrm{NaOH} 0.1 \mathrm{M})$ and oxidation $\left(\mathrm{H}_{2} \mathrm{O}_{2} 3 \%\right)$. Chromatographic studies using HPLC/UV-DAD were performed with this purpose.

During calibration sample analysis, compound VA4J had a retention time of $4.9 \mathrm{~min}$, compound VA6E of $7.3 \mathrm{~min}$ (for both Form I and IV), and compound VA7J of $1.1 \mathrm{~min}$ (for both form I and II).

The linearity showed an adequate relationship between the instrumental response (peak areas) and the respective sample concentration $(x)$. Intra-day precision (Relative Standard Deviation (RSD) $<7 \%$ ) was satisfactorily obtained in the ranges evaluated for the three compounds (Table 6). When new peaks appeared after stress conditions, they were adequately separated from the parent peak.

Table 6. Limit of Quantification (LOQ), linearity data and within-day precision.

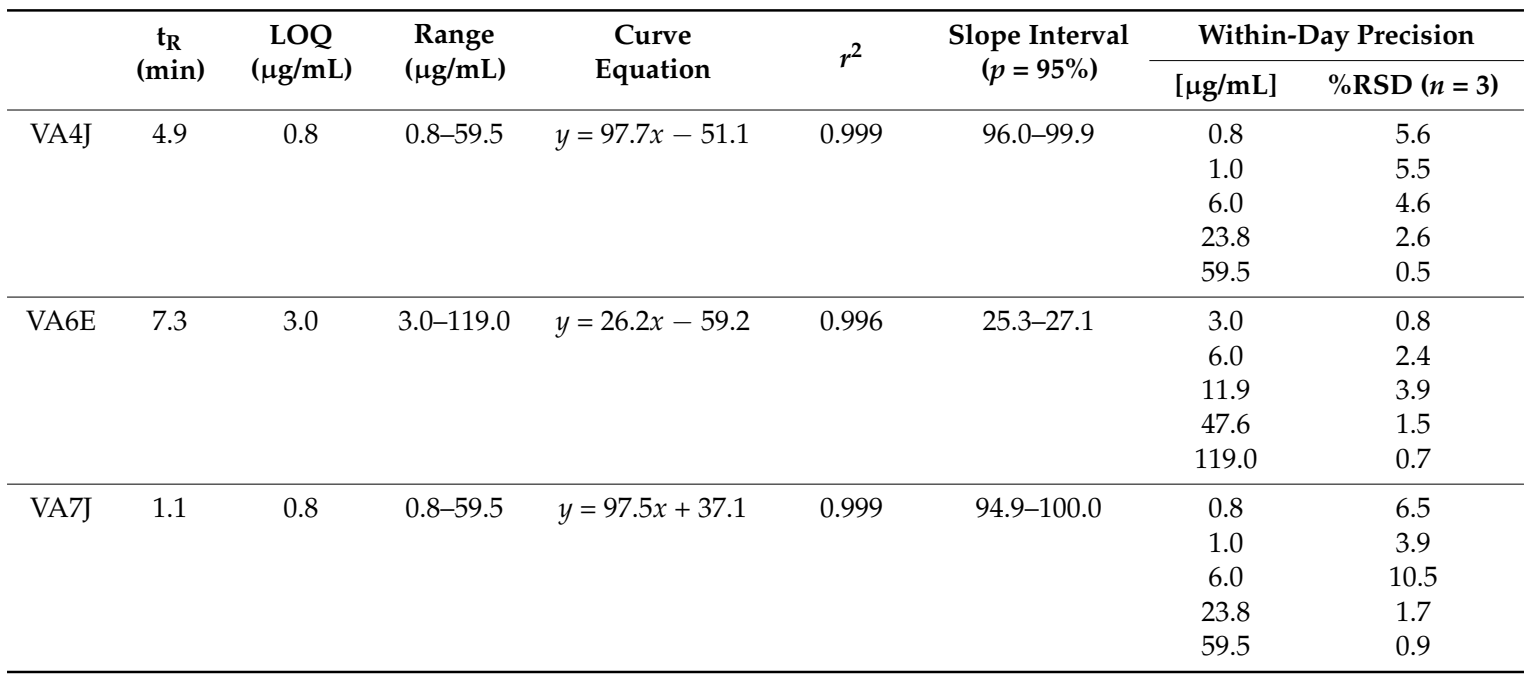

Compound VA6E (Form I and IV)—similar stability for the two polymorphs was found after application of different stress conditions (Figures 9 and 10). The highest degradation occurred in the alkaline medium, as both forms degraded almost completely after $4 \mathrm{~h}$ of exposure to $\mathrm{NaOH}$. Although the stability was higher, degradation product peaks were also detected after acid hydrolysis $\left(t_{R} 3.0 \mathrm{~min}\right)$ and oxidation ( $t_{\mathrm{R}} 3.0,3.5$ and $\left.3.8 \mathrm{~min}\right)$.

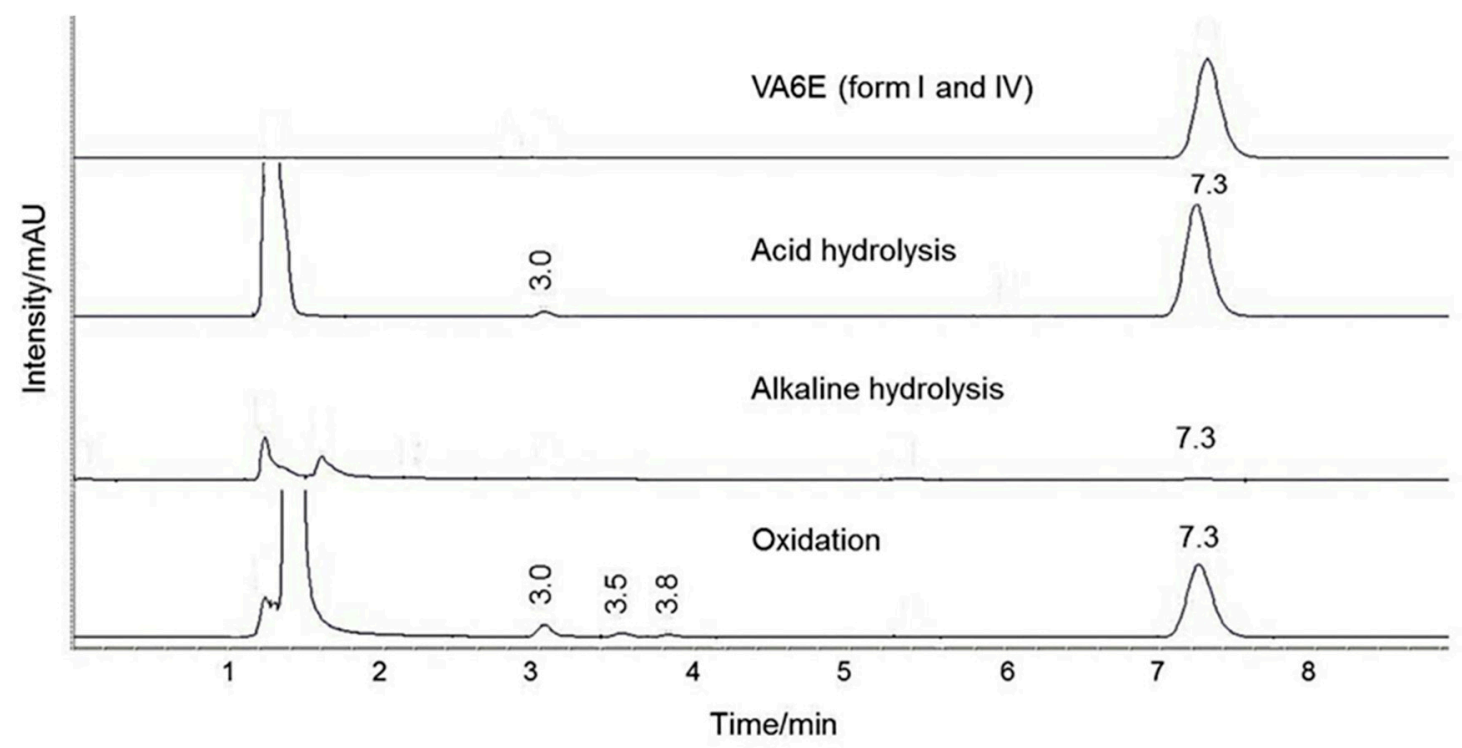

Figure 9. VA6E (form I and IV) chromatogram before and after $24 \mathrm{~h}$ application of diverse stress conditions: acid and alkaline hydrolysis and oxidation. 

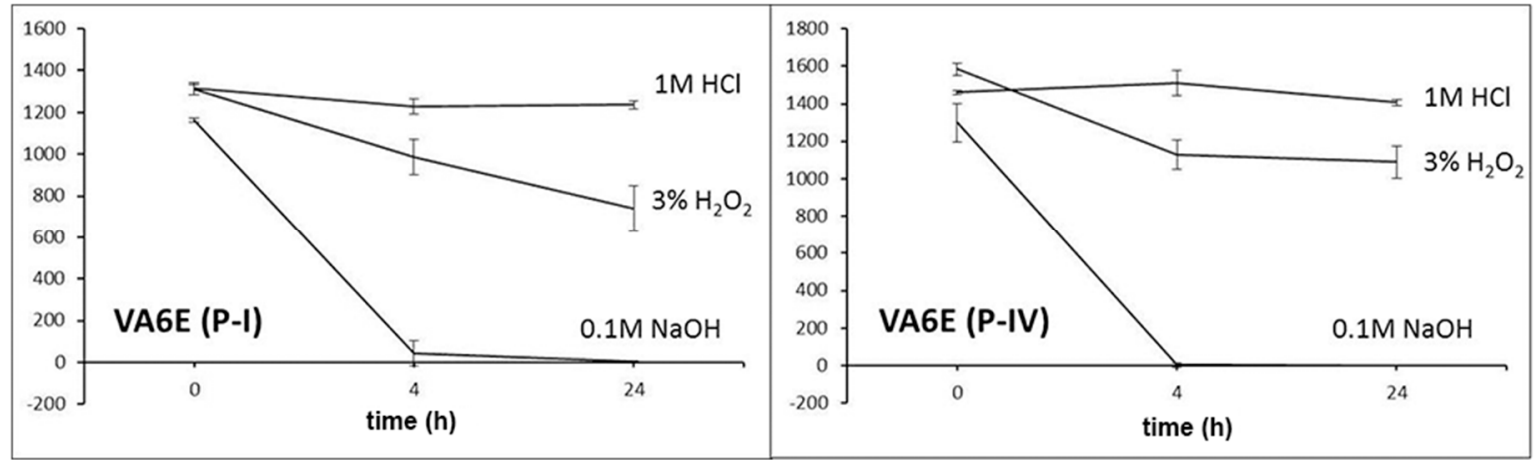

Figure 10. Stability of compound VA6E (polymorph I and IV) after 0,4 and $24 \mathrm{~h}$ of exposition to $\mathrm{HCl}$, $\mathrm{NaOH}$ and $\mathrm{H}_{2} \mathrm{O}_{2}$.

Compound VA4J-The compound was stable after all the stress conditions studied. The VA4J chromatogram before and after $24 \mathrm{~h}$ application of acid and alkaline hydrolysis and oxidation showed no change in the peak area at $4.9 \mathrm{~min} \mathrm{t}_{\mathrm{R}}$ and no new peaks were detected at other retention times (data not shown).

Compound VA7J-The compound was stable to acid hydrolysis and only a minor degradation due to alkaline conditions was detected. However, it totally degraded in the presence of $\mathrm{H}_{2} \mathrm{O}_{2}$, as no peak was detected at its retention time at zero time of exposure to oxidation (Figure 11). A new chromatographic peak was detected at $t_{R}$ of $1.4 \mathrm{~min}$, corresponding to an oxidized form of VA7J, probably an $\mathrm{N}$-oxide derivative.

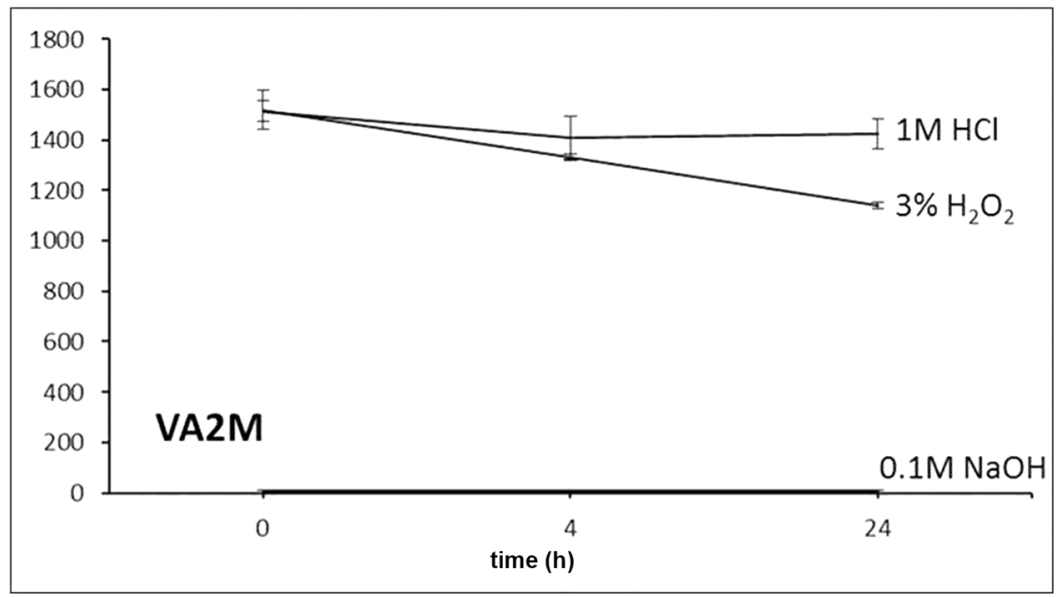

Figure 11. Stability of compound VA7J (polymorph I and II) after application of stress conditions.

\subsection{Polymorphic Behaviours}

To establish general polymorphic behaviours, samples of all the compounds synthetized (Figure 1) were exposed to successive cycles of melting-recrystallization using DSC. Calorimetric analyses were performed before the beginning of the degradation process (Table 6). The analysis of the thermal data revealed interesting calorimetric performance for some of these compounds. The results showed that there are five types of calorimetric behaviours:

- Behaviour I-Compounds that show a polymorphic phase transition into an amorphous or mainly amorphous solid form after a first melting-cooling scan. This behaviour was shown by several compounds: VA1C, VA2E, VA8E, series H, VA6I, VA8J, VA6M and VA8M. DSC and PXRD results of compound VA7H are shown as supplementary material (Figures S1 and S2 and Table S1). 
- Behaviour II-Compounds that change into a new polymorphic form with a different $T_{\text {onset }}$ of fusion than the one observed at the first melting-recrystallization scan after cooling. These compounds are VA7E and VA8O. DSC and PXRD results of compound VA7E are shown as supplementary material (Figures S3 and S4, Table S2).

- Behaviour III-These compounds show a fusion process without modifications in the thermal behaviour after an initial fusion-recrystallization cycle. Consequently, there is no evidence of polymorphic behaviour. The compounds VA2C, VA2M, VA4J and VA5O belong to this group. DSC and PXRD results of compound VA2M are shown as supplementary material (Figures S5 and S6, Table S3).

- Behaviour IV-Compounds that show recrystallization or other types of phase transition of the original form into another crystalline one in the first heat scan. In the successive cycles of melting-recrystallization, the new form may not alter its crystalline form or transit to another polymorphic form. Compounds VA6E, VA7J and VA7M show this behaviour.

- Behaviour $\mathrm{V}$-Compounds without fusion processes at the range of temperatures studied. The original compound shows an amorphous form that does not recrystallize into any crystalline form in the successive melting-recrystallization cycles. The compounds that showed this thermal behaviour are VA2B, VA4B, VA4C, VA1D, VA6D, series G, and VA7O.

Polymorphic behaviour is affected by reaction conditions and purification processes, as they include temperature modifications that can lead to modifications in the final solid state structure. General patterns are therefore difficult to extract as these factors vary among the 12 series. The main skeleton of the structure differs in each of these series and it has a crucial effect on the internal organization.

Some general patterns within each series of compounds can be found. All the derivatives from series B, D and G share the same behaviour (V), those compounds do not suffer transformations due to heating as they only exhibit one polymorphic form (except for compound VA8D that melts with decomposition). In the same line, compounds of series $\mathrm{H}$ exhibit behaviour I, which leads us to think that the conditions for the original crystalline structure to transform to the polymorph were probably not met during the synthetic process. Therefore, the structural nucleus is the main factor that determines internal organization in this series.

Interestingly, the polymorphic behaviour of some of the series changes depending on the substituent. For example, series E shows three different polymorphic behaviours depending on the attached substituent in position 5. Therefore, the substituents play an important role in the calorimetric performance of the resulting derivatives. However, no general patterns could be established in terms of the effect of substituents on internal organization, probably because of the strong effect that main nucleus modifications have among them. Thus, each series should be evaluated independently.

\subsection{Comparative Thermal Stability}

The values of thermal degradation temperatures obtained for the $S$ and Se heteroaryl compounds are also shown in Table 6. Thermal stability is affected by intramolecular interactions and electron delocalization inside the core of the structure, as well as by interactions that might exist between the core and the substituents.

A comparison between compounds substituted with the same chemical group is hard to establish since only compounds 6, 7 and $\mathbf{8}$ are present in most of the mentioned series. Moreover, the variability of the chemical nature of the heterocycles used enables us to observe only general trends in the analysis. For example, quinolone-based structures (series $\mathrm{H}$ ) are less stable with $T_{\text {onset }}$ values of $139.1^{\circ} \mathrm{C}$, $145.8^{\circ} \mathrm{C}$ and $190.2^{\circ} \mathrm{C}$ for the corresponding derivatives 6, 7 and 8, respectively. On the other hand, the structures of series I are among the most stable with $T_{\text {onset }}$ over $220^{\circ} \mathrm{C}$ in all three cases and ranking among the two most stable compounds in derivatives 6,7 and 8 . 
Patterns relating to the substituent nature and thermal stability of the compounds can be spotted when focusing on those compounds with a common core structure (Series B, C, D, E, F, G, H, I, J, M, O and $\mathrm{P}$ ).

Stability is enhanced in structures with the ability to establish hydrogen intermolecular interactions. Overall, $\mathrm{SH}$ (compound 2) or $\mathrm{SeH}$ (compound 1) groups improve stability dramatically. If we look at other substituents that can establish hydrogen interactions such as $-\mathrm{Se}-\mathrm{C}\left(\mathrm{NH}_{2}\right)=\mathrm{NH}$ or $-\mathrm{S}-\mathrm{C}\left(\mathrm{NH}_{2}\right)=\mathrm{NH}$, we can also observe an increase in the thermal stability. Although compounds of series 7 and 8 are homologs except for the presence of Se or $\mathrm{S}$ atoms, $\mathrm{S}$ derivatives are more stable than Se-substituted compounds in general.

Considering the other substituents, compounds with a nitrile ( $\mathrm{CN}$; compounds $\mathbf{5}$ and $\mathbf{6}$ ) or methyl $\left(\mathrm{CH}_{3}\right.$; compounds 4) group showed lower $T_{\text {onset }}$ values of degradation, with this effect being more pronounced for the methyl group. Methyl-substituted structures might be less stable because they do not have the ability to establish either hydrogen interaction.

\section{Materials and Methods}

\subsection{Chemistry}

Proton $\left({ }^{1} \mathrm{H}\right)$ and carbon $\left({ }^{13} \mathrm{C}\right)$ NMR spectra were recorded on a Brüker 400 Ultra-shield ${ }^{\mathrm{TM}}$ spectrometer (Brüker, Rheinstetten, Germany) using DMSO- $d_{6}$ or $\mathrm{CDCl}_{3}$ as solvent. IR spectra were recorded on a Thermo Nicolet FT-IR Nexus spectrophotometer (Thermo Nicolet, Madison, WI, USA) using $\mathrm{KBr}$ pellets for solid samples or $\mathrm{NaCl}$ plates for oil compounds. Elemental analysis was performed on a LECO CHN-900 Elemental Analyzer (LECO, Saint Joseph, MI, USA). The purity of all final compounds was 99\% or higher. Chemicals were purchased from E. Merck (Darmstadt, Germany), Panreac Química S.A. (Barcelona, Spain), Sigma-Aldrich Quimica, S.A. (Madrid, Spain) and Acros Organics (Janssen Pharmaceuticalaan, Geel, Belgium). The synthesis of 34 out of the 40 compounds analysed in this work has been previously described [28,29].

\subsubsection{General Procedure for the Synthesis of Compounds VA6G, VA6H, VA6I and VA6J}

The synthesis (Scheme 1) was carried out from the corresponding alkyl-halide reagent and potassium-thiocyanate in acetone at reflux, as previously described. The corresponding halide reagent $(1 \mathrm{mmol})$ was added to a mixture of $1.2 \mathrm{mmol}$ of potassium thiocyanate in dry acetone $(20 \mathrm{~mL})$. The mixture was stirred at reflux for 3.5-4 $\mathrm{h}$ and the product was isolated by filtration after the addition of $50 \mathrm{~mL}$ of water and purified by washing or recrystallization.

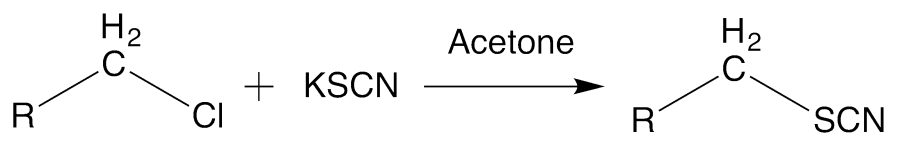

Scheme 1. Reaction scheme to yield compounds VA6G, VA6H, VA6I and VA6J.

\subsubsection{3-Mercaptoquinoxalin-2-yl Carbamimidothioate Hydrochloride (VA2J)}

To obtain compound VA2J, 2,3-dichloroquinoxaline was treated with thiourea in a 1:2.2 (reagent/thiourea) molar ratio (Scheme 2) at reflux for $4 \mathrm{~h}$ using absolute ethanol as solvent $(20 \mathrm{~mL})$. The product was purified by recrystallization from methanol. An orange powder was obtained. Yield: 42\%; melting point (m.p.): $197-198{ }^{\circ} \mathrm{C}$ (direct combustion). ${ }^{1} \mathrm{H}-\mathrm{NMR}$ (400 MHz, DMSO- $\left.d_{6}\right): \delta 7.54$ $(\mathrm{t}, 1 \mathrm{H}, J=7.3 \mathrm{~Hz}, \mathrm{H6}), 7.66-7.72(\mathrm{~m}, 2 \mathrm{H}, \mathrm{H} 5+\mathrm{H7}), 7.90(\mathrm{~d}, 1 \mathrm{H}, J=8.1 \mathrm{~Hz}, \mathrm{H} 8), 9.76+9.95$ (bs + bs, 4H, $\left.\mathrm{NH}+\mathrm{NH}_{2}+\mathrm{HCl}\right), 15.13 \mathrm{ppm}(\mathrm{bs}, 1 \mathrm{H}, \mathrm{SH}) .{ }^{13} \mathrm{C}-\mathrm{NMR}\left(100 \mathrm{MHz}, \mathrm{DMSO}-d_{6}\right): \delta 117.4(\mathrm{C} 6), 127.4(\mathrm{C} 7)$, 128.7 (C5), 131.9 (C8), 132.0 (C4a), 135.6 (C8a), 160.7 (C3), 165.4 (C2), 171.4 ppm (S-C-(NH)( $\left.\mathrm{NH}_{2}\right)$ ). IR (KBr): $\widetilde{v} 3380-3200\left(\mathrm{~s} ; \mathrm{N}-\mathrm{H}, \mathrm{N}-\mathrm{H}_{2}\right), 1625 \mathrm{~cm}^{-1}(\mathrm{~s} ; \mathrm{C}=\mathrm{N}) . \mathrm{MS}$ [ $\mathrm{m} / \mathrm{z}$ (\% abundance)]: 194 (100), 161 
(16), 150 (43), 134 (25). Elemental analysis calculated (\%) for $\mathrm{C}_{9} \mathrm{H}_{8} \mathrm{~N}_{4} \mathrm{~S}_{2} \cdot \mathrm{HCl}: \mathrm{C}: 39.63, \mathrm{H}: 3.33, \mathrm{~N}: 20.54$; found: C: $39.92, \mathrm{H}: 3.61, \mathrm{~N}: 20.19$.

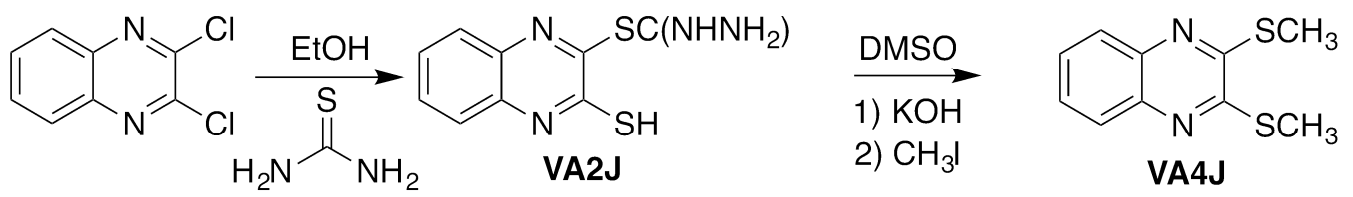

Scheme 2. Synthesis schematics for compounds VA2J and VA4J.

\subsubsection{2,3-Bis(methylsulfanyl)quinoxaline (VA4J)}

VA4J was synthesized by adding $1 \mathrm{mmol}$ of VA2J to a suspension of $3.6 \mathrm{mmol}$ of potassium hydroxide in DMSO (5 mL) and stirring for $1 \mathrm{~h}$ at room temperature (r.t.). Then, $4 \mathrm{mmol}$ of methyl iodide were added and stirred for additional $4 \mathrm{~h}$ at r.t. (Scheme 2). The reaction medium was then poured into ice and the resultant precipitate was filtered and solved in dichloromethane $(40 \mathrm{~mL})$. The insoluble fraction was discarded and the solvent was removed under vacuum by rotatory evaporation. A yellow powder was obtained. Yield: 53\%; mp: $118-119{ }^{\circ} \mathrm{C} .{ }^{1} \mathrm{H}-\mathrm{NMR}(400 \mathrm{MHz}$, $\left.\mathrm{CDCl}_{3}\right): \delta 2.75\left(\mathrm{~s}, 6 \mathrm{H},\left(\mathrm{CH}_{3}\right) \times 2\right), 7.58-7.61(\mathrm{~m}, 2 \mathrm{H}, \mathrm{H} 6+\mathrm{H} 7), 7.91-7.96 \mathrm{ppm}(\mathrm{m}, 2 \mathrm{H}, \mathrm{H} 5+\mathrm{H} 8)$. ${ }^{13} \mathrm{C}-\mathrm{NMR}\left(100 \mathrm{MHz}, \mathrm{DMSO}-d_{6}\right): \delta 13.7\left(\left(\mathrm{CH}_{3}\right) \times 2\right), 128.1(\mathrm{C} 5+\mathrm{C} 8), 129.4(\mathrm{C} 6+\mathrm{C} 7), 139.9(\mathrm{C} 4 \mathrm{a}+\mathrm{C} 8 \mathrm{a})$, 155.3 ppm (C2 + C3). IR (KBr): $\widetilde{v} 2919\left(\mathrm{~m} ; \mathrm{C}-\mathrm{H}_{\text {aliph }}\right), 1615 \mathrm{~cm}^{-1}(\mathrm{~s} ; \mathrm{C}=\mathrm{N})$. MS [ $\mathrm{m} / z$ (\% abundance)]: 222 (52; M+•), 207 (100), 192 (31), 175 (8), 160 (20), 102 (17). Elemental analysis calculated (\%) for $\mathrm{C}_{10} \mathrm{H}_{10} \mathrm{~N}_{2} \mathrm{~S}_{2} \cdot 1 / 2 \mathrm{H}_{2} \mathrm{O}: \mathrm{C}: 51.87, \mathrm{H}: 4.76, \mathrm{~N}: 12.10$; found: C: 51.63, H: 4.56, N: 12.46 .

\subsection{4. (9,10-Dioxo-9,10-dihydroanthracen-2-yl)methyl Thiocyanate (VA6G)}

From 2-(chloromethyl)-9,10-dioxo-9,10-dihydroanthracen. Conditions: $3.5 \mathrm{~h}$ at reflux; recrystallized from ethanol. A yellow powder was obtained. Yield: $46 \%$; m.p.: $174-175{ }^{\circ} \mathrm{C} .{ }^{1} \mathrm{H}-\mathrm{NMR}$ $\left(400 \mathrm{MHz}, \mathrm{DMSO}-d_{6}\right): \delta 4.58\left(\mathrm{~s}, 2 \mathrm{H},-\mathrm{CH}_{2}-\right), 7.93-7.96(\mathrm{~m}, 3 \mathrm{H}, \mathrm{H} 1+\mathrm{H} 3+\mathrm{H} 4), 8.20-8.29 \mathrm{ppm}(\mathrm{m}, 4 \mathrm{H}$, $\mathrm{H} 5+\mathrm{H} 6+\mathrm{H} 7+\mathrm{H} 8) .{ }^{13} \mathrm{C}-\mathrm{NMR}\left(100 \mathrm{MHz}, \mathrm{DMSO}-d_{6}\right): \delta 37.1\left(-\mathrm{CH}_{2}-\right), 113.7(-\mathrm{SCN}), 127.6(\mathrm{C} 5+\mathrm{C} 8)$, 128.0 (C1), 128.3 (C4), 133.4 (C3), 133.8 (C4a), 134.1 (C6 + C7), 135.4 (C8a + C10a), 135.7 (C9a), 144.1 (C2), $183.0 \mathrm{ppm}(\mathrm{C} 9+\mathrm{C} 10)$. IR $(\mathrm{KBr}): \widetilde{v} 2149(\mathrm{~m}, \mathrm{C} \equiv \mathrm{N}), 1671 \mathrm{~cm}^{-1}(\mathrm{~s}, \mathrm{C}=\mathrm{O})$. MS [ $m / z(\%$ abundance $\left.)\right]$ : $279\left(5 ; \mathrm{M}^{+\bullet}\right), 221$ (100), 193 (51), 165 (27). Elemental analysis calculated (\%) for $\mathrm{C}_{16} \mathrm{H}_{9} \mathrm{NO}_{2} \mathrm{~S}: \mathrm{C}: 68.80$, $\mathrm{H}: 3.25, \mathrm{~N}: 5.01$; found: C: 68.59, H: 3.31, N: 4.82 .

\subsubsection{Quinolin-2-ylmethyl Thiocyanate (VA6H)}

The commercially available 2-(chloromethyl)quinoline hydrochloride was treated with basic water $(50 \mathrm{~mL})$ in order to obtain the free base, which was used for the synthesis of VA6H. Conditions: $4 \mathrm{~h}$ at reflux. The precipitate was washed with ethyl ether $(20 \mathrm{~mL})$. A brown powder was obtained. Yield: 41\%; m.p.: 80-81 ${ }^{\circ} \mathrm{C} .{ }^{1} \mathrm{H}-\mathrm{NMR}\left(400 \mathrm{MHz}, \mathrm{DMSO}-d_{6}\right): \delta 4.74\left(\mathrm{~s}, 2 \mathrm{H},-\mathrm{CH}_{2}-\right), 7.63-7.66(\mathrm{~m}, 2 \mathrm{H}, \mathrm{H} 3+\mathrm{H} 6)$, $7.80(\mathrm{t}, 1 \mathrm{H}, J=7.8 \mathrm{~Hz}, \mathrm{H} 7), 8.01(\mathrm{~d}, 2 \mathrm{H}, J=8.6 \mathrm{~Hz}, \mathrm{H} 5+\mathrm{H} 8), 8.44 \mathrm{ppm}(\mathrm{d}, 1 \mathrm{H}, J=8.5 \mathrm{~Hz}, \mathrm{H} 4) .{ }^{13} \mathrm{C}$ NMR (100 MHz, DMSO-d 6 ): $\delta 40.0\left(-\mathrm{CH}_{2}-\right), 113.9$ (-SCN), 121.8 (C3), 127.8 (C6), 127.9 (C4a), 128.8 (C5), 129.3 (C8), 131.0 (C7), 138.2 (C4), 147.8 (C8a), 156.4 ppm (C2). IR (KBr): $\widetilde{v} 3058$ (m; C-Harom), 2946 $\left(\mathrm{m} ; \mathrm{C}-\mathrm{H}_{\text {aliph }}\right), 2147(\mathrm{~s} ; \mathrm{C} \equiv \mathrm{N}), 1655 \mathrm{~cm}^{-1}(\mathrm{~m} ; \mathrm{C}=\mathrm{N}) . \mathrm{MS}\left[\mathrm{m} / \mathrm{z}\left(\%\right.\right.$ abundance)]: $200\left(100 ; \mathrm{M}^{+\bullet}\right), 174(6)$, 142 (100), 128 (9), 115 (47). Elemental analysis calculated (\%) for $\mathrm{C}_{11} \mathrm{H}_{8} \mathrm{~N}_{2} \mathrm{~S} \cdot 1 / 2 \mathrm{H}_{2} \mathrm{O}: \mathrm{C}: 63.08, \mathrm{H}: 4.30$, $\mathrm{N}: 13.99$; found: C: $62.96, \mathrm{H}: 4.42, \mathrm{~N}: 13.15$.

\subsection{6. (6,7-Dimethoxy-2-oxo-2H-chromen-4-yl)methyl Thiocyanate (VA6I)}

From 4-(bromomethyl)-6,7-dimethoxy-2-oxo- $2 \mathrm{H}$-chromene. Conditions: $4 \mathrm{~h}$ at reflux. The product was washed with ethyl ether and dichloromethane $(20 \mathrm{~mL}$ of each). A white powder was obtained. Yield: 70\%; m.p.: $204-205{ }^{\circ} \mathrm{C} .{ }^{1} \mathrm{H}-\mathrm{NMR}\left(400 \mathrm{MHz}, \mathrm{DMSO}-d_{6}\right): \delta 3.83+3.88(\mathrm{~s}, 6 \mathrm{H},(-\mathrm{OCH} 3) \times 2), 4.56$ $\left(\mathrm{s}, 2 \mathrm{H},-\mathrm{CH}_{2}-\right), 6.41$ (s, 1H, H3), 7.13 (s, 1H, H5), 7.38 ppm (s, 1H, H8). ${ }^{13} \mathrm{C}-\mathrm{NMR}\left(100 \mathrm{MHz}, \mathrm{DMSO}-d_{6}\right)$ : 
反 $33.6\left(-\mathrm{CH}_{2}-\right), 57.1+57.3\left(\left(-\mathrm{OCH}_{3}\right) \times 2\right), 101.5(\mathrm{C} 8), 107.2(\mathrm{C} 5), 110.0(-\mathrm{SCN}), 113.3(\mathrm{C} 3), 114.0(\mathrm{C} 4 \mathrm{a})$, 146.9 (C6), 150.4 (C8a), 150.7 (C7), 153.8 (C4), 160.8 ppm (C2). IR (KBr): $\widetilde{v} 3065$ (w; C-Harom), 2999-2849 $\left(\mathrm{m} ; \mathrm{C}-\mathrm{H}_{\text {aliph }}\right), 2154(\mathrm{~s} ; \mathrm{C} \equiv \mathrm{N}), 1711 \mathrm{~cm}^{-1}(\mathrm{C}=\mathrm{O}) . \mathrm{MS}[\mathrm{m} / z(\%$ abundance $)]: 277\left(100 ; \mathrm{M}^{+\bullet}\right), 234$ (6), 219 (27), 191 (69), 147 (18). Elemental analysis calculated (\%) for $\mathrm{C}_{13} \mathrm{H}_{11} \mathrm{NO}_{4} \mathrm{~S}: \mathrm{C}:$ 56.31, H: 4.00, N: 5.05; found: C: $56.40, \mathrm{H}: 3.98, \mathrm{~N}: 4.88$.

\subsubsection{Quinoxalin-2,3-diyldimethanediyl Bisthiocyanate (VA6J)}

From 2,3-bis(bromomethyl)quinoxaline. Conditions: $4 \mathrm{~h}$. at reflux. The product was washed with ethyl ether $(20 \mathrm{~mL})$. A brown powder was obtained. Yield: $88 \%$; m.p.: $158-159{ }^{\circ} \mathrm{C}$ (direct combustion). ${ }^{1} \mathrm{H}-\mathrm{NMR}\left(400 \mathrm{MHz}, \mathrm{DMSO}-d_{6}\right): \delta 4.98\left(\mathrm{~s}, 4 \mathrm{H},\left(-\mathrm{CH}_{2}-\right) \times 2\right), 7.91-7.93$ (m, 2H, H6 + H7), 8.11-8.14 ppm $(\mathrm{m}, 2 \mathrm{H}, \mathrm{H} 5+\mathrm{H} 8) .{ }^{13} \mathrm{C}-\mathrm{NMR}\left(100 \mathrm{MHz}, \mathrm{DMSO}-d_{6}\right): \delta 37.7\left(\left(-\mathrm{CH}_{2}-\right) \times 2\right), 112.0((-\mathrm{SCN}) \times 2), 128.4$ $(\mathrm{C} 5+\mathrm{C} 8), 128.4(\mathrm{C} 6+\mathrm{C} 7), 143.7(\mathrm{C} 4 \mathrm{a}+\mathrm{C} 8 \mathrm{a}), 160.3$ ppm (C2 + C3). IR (KBr): $\widetilde{v} 2926\left(\mathrm{~m} ; \mathrm{C}-\mathrm{H}_{\mathrm{aliph}}\right), 2155$ $(\mathrm{s} ; \mathrm{C} \equiv \mathrm{N}), 1563-1485 \mathrm{~cm}^{-1}$ (m; C-Carom). MS [m/z (\% abundance)]: $272\left(36 ; \mathrm{M}^{+\bullet}\right), 245$ (14), $214(100)$, 187 (15), 170 (13), 155 (30), 129(13). Elemental analysis calculated (\%) for $\mathrm{C}_{12} \mathrm{H}_{8} \mathrm{~N}_{4} \mathrm{~S}_{2}$ : C: 52.92, H: 2.96, N: 20.57; found: C: 52.7, H: 3.07, N: 20.77.

\subsection{Biological Evaluation}

The antitumoural evaluation of 34 out of the 40 compounds analysed in this work has been previously described [28,29].

\subsubsection{Cell Culture}

Cell lines were purchased from the American Type Culture Collection (ATCC, Barcelona, Spain). MCF7 cell lines were grown in Roswell Park Memorial Institute (RPMI) medium (Gibco, Madrid, Spain) supplemented with 10\% fetal bovine serum (FBS; Gibco), 100 units $/ \mathrm{mL}$ penicillin and $100 \mathrm{mg} / \mathrm{mL}$ streptomycin (Gibco, Madrid, Spain). 184B5 cells were grown in DMEM/F12 medium supplemented with 5\% FBS, 1x ITS (Lonza, Barcelona, Spain), 100 nM hydrocortisone (Sigma Aldrich, Madrid, Spain), $2 \mathrm{mM}$ sodium pyruvate (Lonza), $20 \mathrm{ng} / \mathrm{mL}$ EGF (Sigma Aldrich, Madrid, Spain), $0.3 \mathrm{nM}$ trans-retinoic acid (Sigma-Aldrich) 100 units $/ \mathrm{mL}$ penicillin and $100 \mathrm{mg} / \mathrm{mL}$ streptomycin. Cells were maintained at $37^{\circ} \mathrm{C}$ and $5 \% \mathrm{CO}_{2}$.

\subsubsection{Cell Viability}

Compounds were dissolved in DMSO at a concentration of $0.01 \mathrm{M}$. Serial dilutions were prepared with non-supplemented medium. The cytotoxic effect of each compound was tested at eight different concentrations ranging between 0.01 and $100 \mu \mathrm{M}$.

A total of $10^{4}$ cells/well in 96 well-plates were treated with either DMSO or increasing concentrations of the corresponding compound for $72 \mathrm{~h}$ and cell viability was determined using the MTT (3-(4,5-dimethylthiazol-2-yl)-2,5-diphenyltetrazolium bromide) (Sigma Aldrich, Madrid, Spain) assay [33]. Briefly, cells were incubated with $50 \mu \mathrm{L}$ of MTT (2 mg/mL stock) for $4 \mathrm{~h}$. The medium was then removed by aspiration and the formazan crystals were dissolved in $150 \mu \mathrm{L}$ of DMSO. The absorbance was measured at $550 \mathrm{~nm}$ in a microplate reader (Sunrise, Tecan, Männedorf, Switzerland). Results are expressed as $\mathrm{GI}_{50}$, the concentration that reduces by $50 \%$ the growth of treated cells with respect to untreated controls, TGI, the concentration that completely inhibits cell growth, and $\mathrm{LC}_{50}$, the concentration that kills $50 \%$ of the cells. Data were obtained from at least three independent experiments performed in quadruplicate.

\subsection{Thermal Analysis}

The thermogravimetric (TG) studies were carried out with a Perkin-Elmer TGA-7 (Perkin Elmer, Inc. Watham, MA, USA) which was calibrated with alumel and nickel at $10{ }^{\circ} \mathrm{C} \cdot \mathrm{min}^{-1}$. The calibration of the oven temperatures was carried out automatically and mass calibrated with a certified sample of 
$10 \mathrm{mg}$ (ASTM E617, provided by Perkin Elmer, Inc. Watham, MA, USA). TG analyses were performed under a nitrogen atmosphere with a gas flow of $40 \mathrm{~mL} \cdot \mathrm{min}^{-1}$, from 50 to $350{ }^{\circ} \mathrm{C}$, at a heating rate of $10^{\circ} \mathrm{C} \cdot \mathrm{min}^{-1}$, using a sample of approximately $3 \mathrm{mg}$, in order to obtain the values of the $T_{\text {onset }}$ and $\mathrm{T}_{\max }$ of the degradation process as well as any associated mass loss.

For calorimetric studies a Perkin-Elmer DSC diamond calibrated with indium and zinc (provided by Perkin-Elmer (Perkin Elmer, Inc. Watham, MA, USA) and fabricated according to guideline ISO35) at $10^{\circ} \mathrm{C} \cdot \mathrm{min}^{-1}$ and nitrogen flow of $20 \mathrm{~mL} \cdot \mathrm{min}^{-1}$ was employed. The gas connected to the equipment was nitrogen with a purity of $99.999 \%$. Calorimetric analyses were carried out in aluminium capsules for volatilities of $10 \mu \mathrm{L}$, at a heating rate of $10{ }^{\circ} \mathrm{C} \cdot \mathrm{min}^{-1}$, using a sample of approximately $3 \mathrm{mg}$, in order to establish the $T_{\text {onset }}, \mathrm{T}_{\max }$ and the enthalpy of fusion $\Delta \mathrm{H}_{\mathrm{f}}$.

The calorimetric analyses started with the study of the thermal behaviour of the compounds before the process of degradation in order to evidence the possible existence of polymorphism. For this preliminary study, samples of all the compounds were exposed to successive cycles of heating-cooling. All samples were heated from $50{ }^{\circ} \mathrm{C}$ to temperatures $15-20^{\circ} \mathrm{C}$ below $T_{\text {onset }}$ of the degradation process, in order to ensure that compounds were not degraded (Table 6). After melting the samples, they were left at room temperature for enough time to allow the compounds to recrystallize before the successive thermal process. Additional cycles of heating-cooling were performed if polymorphism was detected.

\subsection{Powder X-ray Diffraction}

The X-ray diffraction experiments were performed by using a Bruker D8 Advance diffractometer, under the conditions of a step size of $0.02^{\circ}$ and $1 \mathrm{~s} \mathrm{time/step,} \mathrm{from} 5^{\circ}<2 \theta<40^{\circ}$. The equipment consisted of an X-ray generator with a $\mathrm{Cu}$ anode (radiation $\mathrm{Cu} \mathrm{K} \alpha=1.54 \AA$, $40 \mathrm{kV}, 30 \mathrm{~mA}$ ) and a scillintator detector. Experiments were performed in reflectance mode. Measurements were carried out on samples laid on a glass slide without additional manipulation. The preferential grain orientations that are likely to exist in these compounds could not be avoided due to the absence of grinding of the samples and also to the impossibility of using spinning capillary in our equipment.

\subsection{Chromatography}

Chromatographic studies were performed using an HPLC/UV-DAD (HP 1200, Agilent Technologies. Santa Clara, CA, USA) with a C18 column (Gemini-NX $150 \times 4.6 \mathrm{~mm}, 5 \mu \mathrm{m}$ ) from Phenomenex (Phenomenex. Torrance, CA, USA). The mobile phase was a mixture of acetonitrile/water $(80: 20 ; v / v)$ for compound VA4J, $(50: 50 ; v / v)$ for VA6E and $(80: 20,0.1 \%$ formic acid; $v / v)$ for compound VA7J. The injection volume was $50 \mu \mathrm{L}$ and the flow rate was $1 \mathrm{~mL} / \mathrm{min}$. Chromatography was performed at $35^{\circ} \mathrm{C}$. UV-DAD detection was established at $\lambda=254 \mathrm{~nm}$.

In the assessment of linearity, calibration curves were plotted in the range of $3-119 \mu \mathrm{g} / \mathrm{mL}$ for VA6E and 0.8-59.5 $\mathrm{\mu g} / \mathrm{mL}$ for VA4J and VA7J. Calibration curves were evaluated by the analysis of the distribution properties of the residuals, correlation coefficient $r^{2}>0.990$, slope of the linear calibration curve statistically different from $0(p=95 \%)$ and the intercept not statistically different from $0(p=95 \%)$. Precision (as RSD\%) of the method was evaluated by analysing three replicate calibration samples at five concentration values (including lower, medium and higher value) of the calibration curve.

Stock standard solutions containing $1 \mathrm{mg} / \mathrm{mL}$ of compound VA4J, VA6E and VA7J were prepared by diluting each compound in a mixture of acetonitrile/water $(50: 50 ; v / v)$. Calibration samples in the mobile phase were prepared by the dilution of the stock standard solutions.

For stability evaluation in stress conditions, working solutions of $47.6 \mu \mathrm{g} / \mathrm{mL}$ were prepared by diluting $20 \mu \mathrm{L}$ of each standard solution in $200 \mu \mathrm{L}$ of acetonitrile and $200 \mu \mathrm{L}$ of (a) $1 \mathrm{M} \mathrm{HCl}$, (b) $0.1 \mathrm{M}$ $\mathrm{NaOH}$ and (c) $3 \% \mathrm{H}_{2} \mathrm{O}_{2}$. Data were recorded at zero time and after 4 and $24 \mathrm{~h}$ of exposure.

\section{Conclusions}

The thermal characterization of compounds with antitumour potency is crucial to further continue the drug discovery process. In order to predict the non-desired transformations that might occur in 
the pharmaceutical manufacturing process, the polymorphism of the most promising compounds has been studied.

Regarding the results of differential scanning calorimetry, powder X-ray diffraction and the stability studies under stress conditions:

- $\quad$ Compound VA6E: temperature conditions have to be carefully selected as solid state behaviour includes four different polymorphs. In terms of stability, alkaline, acid and oxidation media are not suggested as they cause degradation.

- Compound VA7J: oxidation conditions and desolvation have to be taken into account as they lead to immediate degradation and crystal structure modification, respectively.

- Compound VA4J: there is no evidence of polymorphism and stress conditions do not affect the solid-state structure.

Taken together we can conclude that compounds VA6E and VA7J present some obstacles to further development as drugs as both temperature and stress conditions affect the original structure. On the other hand, compound VA4J proved to be safe to work with under the conditions studied. Therefore, this compound is of special interest for further development as it shows promising activity, selectivity and stability.

In addition, it has been found that the polymorphic behaviour as well as the thermal stability of these compounds can be modified by the introduction of different functional groups in the heterocycle under consideration. According to our data, the incorporation of a selenol or thiol group improves the thermal stability.

Supplementary Materials: supplementary material are available online.

Acknowledgments: The authors wish to express their gratitude to the Plan de Investigación de la Universidad de Navarra, PIUNA (Ref 2014-26), for financial support for the project. V. Alcolea and P. Garnica wish to express their gratitude to the Asociación de Amigos de la Universidad de Navarra for the pre-doctoral fellowship. The research leading to these results has received funding from "la Caixa" Banking Foundation.

Author Contributions: Carmen Sanmartín, Elena Lizarraga and Juan Antonio Palop conceived and designed the experiments; Verónica Alcolea performed the synthesis of the compounds; Pablo Garnica performed the biological evaluation, Elena Lizarraga the experiments in thermal analysis; Adrian Durán the experiments in X-ray diffraction and Elena González Peñas designed and performed the experiments in HPLC. Elena Lizarraga, Elena González Peñas, Adrián Durán, Pablo Garnica, Verónica Alcolea and Carmen Sanmartín analyzed the data; all the authors wrote the paper.

Conflicts of Interest: The authors declare no conflict of interest.

\section{References}

1. World Health Organization. Cancer Fact Sheet February 2017; World Health Organization: Geneva, Switzerland, 2017.

2. Siegel, R.L.; Miller, K.D.; Jemal, A. Cancer statistics, 2017. CA Cancer J. Clin. 2017, 67, 7-30. [CrossRef] [PubMed]

3. Holohan, C.; Van Schaeybroeck, S.; Longley, D.B.; Johnston, P.G. Cancer drug resistance: An evolving paradigm. Nat. Rev. Cancer 2013, 13, 714-726. [CrossRef] [PubMed]

4. Miller, K.D.; Siegel, R.L.; Lin, C.C.; Mariotto, A.B.; Kramer, J.L.; Rowland, J.H.; Stein, K.D.; Alteri, R.; Jemal, A. Cancer treatment and survivorship statistics, 2016. CA Cancer J. Clin. 2016, 66, 271-289. [CrossRef] [PubMed]

5. Wallenberg, M.; Misra, S.; Bjornstedt, M. Selenium cytotoxicity in cancer. Basic Clin. Pharmacol. Toxicol. 2014, 114, 377-386. [CrossRef] [PubMed]

6. Fernandez-Herrera, M.A.; Sandoval-Ramirez, J.; Sanchez-Sanchez, L.; Lopez-Muñoz, H.; Escobar-Sanchez, M.L. Probing the selective antitumour activity of 22-oxo-26-selenocyanocholestane derivatives. Eur. J. Med. Chem. 2014, 74, 451-460. [CrossRef] [PubMed]

7. Romano, B.; Plano, D.; Encio, I.; Palop, J.A.; Sanmartin, C. In vitro radical scavenging and cytotoxic activities of novel hybrid selenocarbamates. Bioorg. Med. Chem. 2015, 23, 1716-1727. [CrossRef] [PubMed] 
8. Plano, D.; Sanmartín, C.; Moreno, E.; Prior, C.; Calvo, A.; Palop, J.A. Novel potent organoselenium compounds as cytotoxic agents in prostate cancer cells. Bioorg. Med. Chem. Lett. 2007, 17, 6853-6859. [CrossRef] [PubMed]

9. Otsuka, M.; Kaneniwa, N. Dehydration of cephalexin hydrates. Chem. Pharm. Bull. 1983, 31, 1021-1029. [CrossRef]

10. Borka, L.; Haleblian, J.K. Crystal polymorphism of pharmaceuticals. Acta Pharm. Jugosl. 1990, 40, 71-94.

11. Takahashi, Y.; Nakashima, K.; Ishihara, T.; Nakagawa, H.; Sugimoto, I. Polymorphism of fostedil: Characterization and polymophic change by mechanical treatments. Drug Dev. Ind. Pharm. 2008, 11, 1543-1563. [CrossRef]

12. Correa, J.C.R.; Perissinato, A.G.; Serra, C.H.D.; Trevisan, M.G.; Salgado, H.R.N. Polymorphic stability of darunavir and its formulation. J. Therm. Anal. Calorim. 2016, 123, 2185-2190. [CrossRef]

13. Bonfilio, R.; Pires, S.A.; Ferreira, L.M.; de Almeida, A.E.; Doriguetto, A.C.; de Araujo, M.B.; Salgado, H.R. A discriminating dissolution method for glimepiride polymorphs. J. Pharm. Sci. 2012, 101, 794-804. [CrossRef] [PubMed]

14. Giron, D. Thermal-analysis and calorimetric methods in the characterization of polymorphs and solvates. Thermochim. Acta 1995, 248, 1-59. [CrossRef]

15. Du, Y.; Xue, J. Investigation of polymorphism and cocrystallization of active pharmaceutical ingredients using vibrational spectroscopic techniques. Curr. Pharm. Des. 2016, 22, 4917-4928. [CrossRef] [PubMed]

16. Barnes, A.F.; Hardy, M.J.; Lever, T.J. A review of the applications of thermal methods within the pharmaceutical-industry. J. Therm. Anal. 1993, 40, 499-509. [CrossRef]

17. Wang, L.Y.; Zhu, L.; Sha, Z.L.; Li, X.C.; Wang, Y.F.; Yang, L.B.; Zhao, X.Y. Characterization, thermal stability, and solid-state phase transition behaviors of gestodene polymorphs and amorphous phase. J. Therm. Anal. Calorim. 2017, 127, 1533-1542. [CrossRef]

18. Waszkielewicz, A.M.; Cegla, M.; Zeslawska, E.; Nitek, W.; Sloczynska, K.; Marona, H. $\mathrm{N}$-[(2,6-dimethylphenoxy)alkyl]aminoalkanols-their physicochemical and anticonvulsant properties. Bioorg. Med. Chem. 2015, 23, 4197-4217. [CrossRef] [PubMed]

19. Jiang, S.F.; Jansens, P.J.; ter Horst, J.H. Mechanism and kinetics of the polymorphic transformation of o-aminobenzoic acid. Cryst. Growth Des. 2010, 10, 2123-2128. [CrossRef]

20. Da Silva, L.M.; Montanari, C.M.; Santos, O.M.; Cazedey, E.C.; Angelo, M.L.; de Araujo, M.B. Quality evaluation of the finasteride polymorphic forms i and ii in capsules. J. Pharm. Biomed. Anal. 2015, 105, $24-31$. [CrossRef] [PubMed]

21. Carrer, H.; Cortez, J.; Frare, L.M.; Costa, M.B.; Bittencourt, P.R.S. Thermal characterization of the bromopride recrystallized from different solvents and at different temperature conditions. J. Therm. Anal. Calorim. 2016, 123, 927-931. [CrossRef]

22. Yoshida, M.I.; Gomes, E.C.; Soares, C.D.; Cunha, A.F.; Oliveira, M.A. Thermal analysis applied to verapamil hydrochloride characterization in pharmaceutical formulations. Molecules 2010, 15, 2439-2452. [CrossRef] [PubMed]

23. Huang, L.F.; Tong, W.Q. Impact of solid state properties on developability assessment of drug candidates. Adv. Drug. Deliv. Rev. 2004, 56, 321-334. [CrossRef] [PubMed]

24. Thomas, S.P.; Satheeshkumar, K.; Mugesh, G.; Guru Row, T.N. Unusually short chalcogen bonds involving organoselenium: Insights into the Se-N bond cleavage mechanism of the antioxidant ebselen and analogues. Chem. Eur. J. 2015, 21, 6793-6800. [CrossRef] [PubMed]

25. Neumann, M.A.; Van de Streek, J.; Fabbiani, F.P.; Hidber, P.; Grassmann, O. Combined crystal structure prediction and high-pressure crystallization in rational pharmaceutical polymorph screening. Nat. Commun. 2015, 6, 7793. [CrossRef] [PubMed]

26. Nauha, E.; Bernstein, J. “Predicting” polymorphs of pharmaceuticals using hydrogen bond propensities: Probenecid and its two single-crystal-to-single-crystal phase transitions. J. Pharm. Sci. 2015, 104, 2056-2061. [CrossRef] [PubMed]

27. Xu, K.; Zheng, S.; Zhai, Y.; Guo, L.; Tang, P.; Yan, J.; Wu, D.; Li, H. Two solid forms of tauroursodeoxycholic acid and the effects of milling and storage temperature on solid-state transformations. Int. J. Pharm. 2015, 486, 185-194. [CrossRef] [PubMed] 
28. Alcolea, V.; Plano, D.; Encio, I.; Palop, J.A.; Sharma, A.K.; Sanmartin, C. Chalcogen containing heterocyclic scaffolds: New hybrids with antitumoural activity. Eur. J. Med. Chem. 2016, 123, 407-418. [CrossRef] [PubMed]

29. Alcolea, V.; Plano, D.; Karelia, D.N.; Palop, J.A.; Amin, S.; Sanmartin, C.; Sharma, A.K. Novel seleno- and thio-urea derivatives with potent in vitro activities against several cancer cell lines. Eur. J. Med. Chem. 2016, 113, 134-144. [CrossRef] [PubMed]

30. Plano, D.; Baquedano, Y.; Moreno-Mateos, D.; Font, M.; Jiménez-Ruiz, A.; Palop, J.A.; Sanmartín, C. Selenocyanates and diselenides: A new class of potent antileishmanial agents. Eur. J. Med. Chem. 2011, 46, 3315-3323. [CrossRef] [PubMed]

31. Wang, L.; Guo, X.; Wang, J.; Jiang, C.; Bosland, M.C.; Lu, J.; Deng, Y. Methylseleninic acid superactivates p53-senescence cancer progression barrier in prostate lesions of pten-knockout mouse. Cancer Prev. Res. 2016, 9, 35-42. [CrossRef] [PubMed]

32. Fernandes, A.P.; Gandin, V. Selenium compounds as therapeutic agents in cancer. Biochim. Biophys. Acta 2015, 1850, 1642-1660. [CrossRef] [PubMed]

33. Lamberto, I.; Plano, D.; Moreno, E.; Font, M.; Palop, J.A.; Sanmartin, C.; Encio, I. Bisacylimidoselenocarbamates cause $\mathrm{g}^{2} / \mathrm{m}$ arrest associated with the modulation of cdk1 and chk2 in human breast cancer mcf-7 cells. Curr. Med. Chem. 2013, 20, 1609-1619. [CrossRef] [PubMed]

Sample Availability: Samples of the compounds reported in this paper are available from the authors. 